\title{
Henryk Bartoszewicz
}

Warszawa

\section{Romana Knolla oceny przeszłości i wizje przyszłości}

Opracowania i memoriały Romana Knolla dotyczące spraw międzynarodowych, polskiej polityki zagranicznej i problemów narodowościowych, sporządzone między marcem $1939 \mathrm{r}$. a kwietniem 1944 r., wywoływały wiele emocji u współczesnych ich autorowi, nie są też obojętne badaczom dziejów XX w. O ile przedmiotem zainteresowania polityków u schyłku II Rzeczypospolitej i w okresie drugiej wojny światowej były głównie poglądy Knolla w kwestii polityki zagranicznej, o tyle historycy częściej odnoszą się do poruszanej przez niego problematyki narodowościowej. Sądzę, że warto spojrzeć na całość poglądów i ocen, jakie wówczas formułował ten polityk i dyplomata.

Przed przystąpieniem do analizy opracowań i memoriałów Knolla warto przedstawić sylwetkę ich autora. Dominik Węgierski w Przedmowie do broszury napisanej przez Romana Knolla w okupowanym kraju i opublikowanej w 1941 r. w Londynie pod pseudonimem Lucjan Bielski, zatytułowanej Głos z kraju czyli uwagi Polaka o ustroju przyszłej Europy, trafnie pisał o nim: „Przed wojną w Polsce znano autora i ceniono go zarówno dla jego wysokiej inteligencji jak fachowej wiedzy. Miał wpływ na ludzi i liczono się z jego zdaniem. Doświadczony polityk, wybitny znawca administracji państwowej i samorządowej, spostrzegł wcześnie kierunek polityki europejskiej i zgubną drogę, po której się posuwała. Widział szalbierstwa Niemiec, głupotę Ligi Narodów, dojrzał chytrą postawę Rosji. Spostrzegł zaślepienie, pychę, blagę, które i w naszym życiu wraz z brakiem smaku, kultury i moralności, niestety, zaczęły brać górę"1.

Tę charakterystykę autora Głosu z kraju należy uzupełnić przynajmniej podstawowymi faktami z jego biografii politycznej. Roman Knoll był politykiem i dyplomatą o dużej aktywności i szerokich zainteresowaniach międzynarodowych, nie lekceważył też problemów wewnętrznych Rzeczypospolitej. Od lat szkolnych należał do kijowskich organizacji, których działalność była skierowana przeciwko rosyjskiemu zaborcy. W ruchu niepodległościowym działał także w okresie studiów. Wzrost jego aktywności politycznej nastąpił w okresie pierwszej wojny światowej, zwłaszcza w jej końcowej fazie, po obaleniu caratu w Rosji. Służbę dyplomatyczną Knoll rozpoczął jako jeden z dwóch, obok Juliusza Łukasiewicza, członków sekretariatu politycznego Przedstawicielstwa Rady Regencyjnej w Rosji, kierowanego przez Aleksandra Lednickiego. Następnie w Departamencie Stanu Rady Regencyjnej zajmował się sprawami Rosji i Ukrainy. Po odzyskaniu przez Polskę niepodległości podjął

${ }^{1}$ D. Węgierski, Przedmowa, w: L. Bielski, Głos z kraju czyli uwagi Polaka o ustroju przeszłej Europy, Londyn 1941, s. 3. 
pracę w Wydziale Wschodnim MSZ. W latach 1919-1920 uczestniczył w negocjacjach prowadzonych z Ukraińcami, zakończonych podpisaniem 21 IV 1920 r. dwustronnego paktu politycznego ${ }^{2}$. Brał udział w rokowaniach pokojowych w Rydze, potem jego działalność koncentrowała się wokół spraw związanych z wykonaniem postanowień traktatu ryskiego. Od 4 VIII 1921 r był radcą poselstwa RP w Rosji sowieckiej, następnie od października 1922 do grudnia 1923 r. kierował tą placówką w randze chargé d'affaires ${ }^{3}$. W latach 1924-1926 był posłem RP w Ankarze4 . Po przewrocie majowym w 1926 r. objął urząd podsekretarza stanu (wiceministra) w MSZ. Doświadczenie życiowe i polityczne, wiedza akademicka, a później praktyka dyplomatyczna uczyniły z niego wybitnego znawcę spraw Wschodu, w tym przede wszystkim Rosji, a później Rosji bolszewickiej i Związku Sowieckiego. W sprawy polskiej polityki wschodniej angażował się także w następnych latach jako wiceminister spraw zagranicznych (maj-grudzień 1926 r.), a następnie poseł w Rzymie (1926-1928) i w Berlinie (1928-1931) oraz pełniąc obowiązki szefa polskiej dyplomacji (lipiec-grudzień 1927 r.)5.

Trudno jednoznacznie opowiedzieć na pytanie, jakie były przyczyny odwołania Knolla z Berlina, a także jego późniejszego usunięcia z MSZ. Jest mało prawdopodobne, aby jedynym powodem był jego krytyczny stosunek do coraz częstszego kierowania do pracy w dyplomacji niedoświadczonych, lecz bardzo pewnych siebie oficerów ${ }^{6}$. Nawet Alfred Wysocki, niezbyt przychylny swojemu poprzednikowi na stanowisku posła w Berlinie, stwierdzał, że Knoll został odwołany z placówki w Niemczech wbrew woli ministra Augusta Zaleskiego, który swojego byłego zastępcę w resorcie spraw zagranicznych chciał wysłać jesienią $1930 \mathrm{r}$. do Ankary. Jednocześnie dodawał: „Przyczyny, dla których Knoll przestał być dobrze widziany w Belwederze, były mi nieznane" coraz większy krąg osób nieprzychylnych Zaleskiemu i jego najbliższym współpracownikom. Środowisko to wykorzystało przeciwko Knollowi zarówno jego krytyczny stosunek do polityki obozu rządzącego ${ }^{8}$, jak i popełnione przez niego pewne niezręczności, chociażby

${ }^{2}$ H. Bartoszewicz, Roman Knoll wobec sprawy niepodległości Ukrainy 1917-1921. Z dziejów prometeizmu polskiego, w: Polska i jej wschodni sąsiedzi 2005, t. VI, s. 11-30; P. Wandycz, Z zagadnień wspótpracy polsko-ukraińskiej w latach 1919-1920, „Zeszyty Historyczne”, z. 12, Paryż 1967, s. 11 i n.

${ }^{3}$ H. Bartoszewicz, Okres rosyjski w karierze dyplomatycznej Romana Knolla, cz. 1, „Studia z Dziejów Rosji i Europy Środkowo-Wschodniej” 2004, t. XXXIX, s. 63-82; cz. 2, „Studia z Dziejów Rosji i Europy Środkowo-Wschodniej” 2005, t. XL, s. 63-80; W. Kamieniecki, Historycy i politycy warszawscy 1900-1950, Wrocław 1992, s. 146, 147.

${ }^{4}$ H. Bartoszewicz, Misja Romana Knolla w Ankarze 1924-1925, „Studia z Dziejów Rosji i Europy Środkowo-Wschodniej” 2001, t. XXXVI, s. 109-125; W. Stępniak, Dyplomacja polska na Bałkanach (1918-1926), Warszawa 1998, s. 338-342.

${ }_{5}$ H. Bartoszewicz, Misja dyplomatyczna Romana Knolla w Rzymie, „Dzieje Najnowsze” 2011, r. XLIII, nr 1, s. 59, 61-63.

${ }^{6}$ Komentując to zjawisko, Knoll miał posłużyć się cytowanym we wspomnieniach dyplomatów powiedzeniem: „A to najście zbirów na przytułek dla idiotów”. Cyt. za przytoczoną przez Piotra Wandycza notatką A. Zaleskiego. P. Wandycz, Z Piłsudskim i Sikorskim. August Zaleski minister spraw zagranicznych w latach 1926-1932 i 1939-1941, Warszawa 1999, s. 142. Zob. też. R. Wodzicki, Wspomnienia. Gdańsk - Warszawa - Berlin 1928-1939, Warszawa 1972, s. 263; W. Michowicz, Organizacja polskiego aparatu dyplomatycznego w latach 1918-1939, w: Historia dyplomacji polskiej, t. IV: 19181939, red. P. Łossowski, Warszawa 1995, s. 40; W. Kamieniecki, op. cit., s. 145.

${ }^{7}$ A. Wysocki, Dzieje mojej służby 1900-1938 (maszynopis), Zakład Naukowy im. Ossolińskich, Dział Rękopisów, 12477/II, t. I, s. 174.

${ }^{8}$ W. Kamieniecki, op. cit., s. 148. Witold Kamieniecki stwierdza, że raporty Knolla przesłane do MSZ z Berlina zawierały wiele ,zjadliwych krytycznych uwag o działalności centralnych władz warszawskich", co potwierdza lektura tych dokumentów. 
wniosek o sześciomiesięczny urlop bezpłatny w okresie bezwzględnej walki przedwyborczej w Polsce, czy też przyjęcie w poselstwie w Berlinie generała Władysława Sikorskiego. O końcu kariery w MSZ tego zdolnego i doświadczonego dyplomaty przesądziło ostatecznie przyjście tam Józefa Becka. Podsekretarz stanu, a od 2 XI 1932 r. minister spraw zagranicznych, nie ukrywał swojej niechęci do Knolla, a ten z kolei nie pochwalał metod działania nowego przełożonego9. Opuszczenie placówki berlińskiej 20 XII 1930 r. było faktycznym zakończeniem kariery dyplomatycznej Romana Knolla ${ }^{10}$.

Po definitywnym odejściu z pracy w MSZ 1 III 1932 r. w następnym miesiącu Roman Knoll powrócił do pracy w adwokaturze ${ }^{11}$. Nie było to jednoznaczne z całkowitym porzuceniem polityki. Knoll nie przestał interesować się problemami polskiej polityki zagranicznej, w tym przede wszystkim polityką wschodnią. Utrzymywał kontakty z szerokim gronem kolegów i przyjaciół, zarówno czynnych politycznie czy pozostających w służbie dyplomatycznej, jak i tych, którzy wówczas wbrew własnej woli opuścili Wierzbową. Spotykał się na gruncie towarzyskim między innymi ze swoim przyjacielem i byłym szefem Augustem Zaleskim oraz z marszałkiem Edwardem Rydzem-Śmigłym. Kontaktował się także z politykami opozycyjnymi, głównie związanymi z Frontem Morges. Jednocześnie zaangażował się w działalność publicystyczną. Na początku lat trzydziestych XX w. rozpoczął współpracę z polską prasą, komentując między innymi na łamach „Expressu Porannego” ważne wydarzenia międzynarodowe.

W marcu 1939 r. Knoll opublikował broszurę Uwagi o polskiej polityce 1939, poświęconą pozycji politycznej Polski w Europie. Autor zawarł w niej swoje przemyślenia dotyczące stanu państwa polskiego na przełomie 1938 i 1939 r. i zagrożeń, wobec jakich stanęła wówczas Rzeczpospolita. Jego zdaniem istniała pilna konieczność, aby „świadome elementy" narodu polskiego zainteresowały się sprawami politycznymi. Za ważny uznał także problem mniejszości narodowych. Rozważania na ten temat rozpoczął od interesującej, chociaż dyskusyjnej konstatacji: „Naród polski przy upadku dawnej Rzeczypospolitej to wszystkie jej ludy i plemiona mówiące poza polską mową literacką, narzeczami polskimi, ruskimi, czy litewskimi, ale naród polski w chwili naszego narodowego zmartwychwstania, to już tylko ludzie mówiący po polsku, bo inni się odpolszczyli przez rozbiorców"12. Konsekwencją tej tezy jest stwierdzenie Knolla, iż II Rzeczpospolita była państwem narodowym, o którego egzystencji i sile decydował naród polski. W związku z tym należy odpowiedzieć na pytanie, jak postrzegał on problem mniejszości narodowych w Polsce. „Białorusini polscy — jego zdaniem — powinni się w polskim narodzie rozpłynąć jako jeden z jego szczepów”. Teza ta była co najmniej dyskusyjna, podobnie

\footnotetext{
9 Ibidem, s. 149; R. Wodzicki, op. cit., s. 263; H. Bartoszewicz, Polityka wschodnia II Rzeczypospolitej w świetle polskich dokumentów dyplomatycznych 1931 r., „Dzieje Najnowsze” 2009, r. XXXI, nr 4, s. $128-130$.

${ }^{10}$ Knoll oficjalnie został odwołany ze stanowiska posła RP w Berlinie 10 I $1931 \mathrm{r}$. W tym samym dniu posłem RP w Berlinie został mianowany A. Wysocki. Dziennik Urzędowy MSZ RP 1931, r. XIII, nr 3, poz. 22, s. 26. Po powrocie do centrali z urlopu wypoczynkowego i po upływie półrocznego urlopu bezpłatnego Knoll został z dniem 1 VIII 1931 r. przeniesiony w stan rozporządzalności, a z dniem 1 III 1932 r. w stan spoczynku. „Dziennik Urzędowy MSZ RP” 1931, r. XIII, nr 16, poz. 65, s. 199; „Dziennik Urzędowy MSZ RP” 1932, r. XIV, nr 4, poz. 25, s. 82.

1118 IV 1932 r. „Gazeta Sądowa Warszawska” opublikowała informację Rady Adwokackiej Okręgu Sądu Apelacyjnego w Warszawie, że zgłosił się do niej o przyjęcie w poczet adwokatów „Roman Knoll b. podsekretarz stanu w ministerstwie spraw zagranicznych, poseł w Rzymie i Berlinie z siedzibą w Warszawie (ul. Górnośląska 18)”, „Gazeta Sądowa Warszawska” 1932, r. LX, nr 16, s. 227.

12 R. Knoll, Uwagi o polskiej polityce 1939, Warszawa 1939, s. 9.
} 
jak zawarte w Uwagach stwierdzenie, że w Polsce na początku 1939 r. właściwie nie było „wewnętrznego zagadnienia niemieckiego"13.

Inaczej postrzegał Knoll kwestię pozostającej w granicach Rzeczypospolitej mniejszości ukraińskiej. Uważał, że ma ona poczucie narodowe, a wszelkie zabiegi polskich władz państwowych zmierzające do spolszczenia Kresów południowo-wschodnich w okresie dwudziestu lat niepodległości nie przyniosły żadnych rezultatów. Ponadto dodał, że „właściwa Ukraina", leżąca na wschód od naszej [polskiej - H. B.] granicy państwowej, nie żyje życiem narodowym i wskutek tego na naszym terytorium utworzyło się coś w rodzaju Piemontu dla ukraińskich narodowych marzeń i temperamentów". Autor Uwag nie przedstawił jednak żadnej koncepcji dotyczącej polskiej polityki wobec mniejszości ukraińskiej. Ograniczył się jedynie do ogólników, konieczności stworzenia dogodnych warunków do rozwijania „,narodowej kultury” i prowadzenia „twórczej pracy organizacyjnej” na Kresach Rzeczypospolitej ${ }^{14}$.

Więcej szczegółów zawierał projekt Knolla dotyczący rozwiązania kwestii mniejszości żydowskiej w Polsce. Dzisiaj stwierdzenia zawarte w tej części Uwag mogą wydawać się trudne do zaakceptowania, ale wówczas nie były niczym wyjątkowym nie tylko w porównaniu z projektami pojawiającymi się w państwach środkowoeuropejskich, w tym w Polsce ${ }^{15}$, ale także $\mathrm{w}$ odniesieniu do koncepcji funkcjonujących w środowiskach żydowskich na temat utworzenia własnego państwa narodowego. Knoll stwierdzał, że problem żydowski nie tylko w Polsce, ale także na Ukrainie sowieckiej, w Rumunii i na Węgrzech można byłoby rozwiązać w porozumieniu z organizacjami syjonistycznymi, które nie upierałyby się przy Palestynie jako miejscu osiedlenia Żydów, tworząc państwo żydowskie na wybrzeżu Morza Czarnego, na terytorium dawnego Kaganatu Chazarskiego ${ }^{16}$. Autor tego mało realistycznego pomysłu nie wskazał jednak dróg prowadzących do jego realizacji.

Zasadniczym przedmiotem rozważań Knolla zawartych w Uwagach są oceny sytuacji międzynarodowej i polskiej polityki zagranicznej dwudziestolecia międzywojennego. Autor wskazywał przede wszystkim niebezpieczeństwa grożące Rzeczypospolitej. Dobitnie starał się przekonać polityków i opinię publiczną o skali zagrożeń, pisząc: „Kocioł sowiecki nic nie jest mniej groźny od mocarstwa Piotra i Katarzyny, trzecia zaś Rzesza niemiecka wielokrotnie niebezpieczniejsza jest od Prus Fryderyka i cesarstwa Marii Teresy. Państwa zaś, wśród których szukaliśmy i szukać możemy pomocy, są dziś w porównaniu do naszych wielkich sąsiadów słabsze niż ongiś. Francja przedstawia połowę Niemiec. Szwecja nie jest mocarstwem. Turcja cofnęła się z Europy"17.

Autor opracowania wiele uwagi poświęcił polskiej polityce wschodniej. Zmienił on swój wcześniejszy stosunek do koncepcji federacyjnej. Knoll w tej kwestii stał się bardziej sceptyczny, podkreślając, że ,nikt z nami federować się nie chciał"'18. Natomiast nie uległy zmianie jego poglądy w sprawie rosyjskiej i zagrożeń Polski ze strony Rosji. Za najgroźniejsze narzędzie agresji sowieckiej w warunkach pokojowych uważał międzynarodowy komunizm, podkreślając, że

\footnotetext{
13 Ibidem, s. 10.

${ }^{14}$ Ibidem, s. $10-12$.

${ }^{15}$ Znacznie bardziej zaskakujący jest fakt, że w tym samym czasie, kiedy Knoll pisał swoje Uwa$g i$, podczas rozmów polsko-niemieckich obydwa państwa deklarowały gotowość współdziałania przy organizowaniu emigracji ludności żydowskiej z Polski. Ambasador RP w Berlinie Józef Lipski miał rzekomo w rozmowie z Adolfem Hitlerem obiecać mu „piękny pomnik” w Warszawie, jeśli udałoby się znaleźć rozwiązanie „kwestii żydowskiej”. R.D. Müller, Wspólny wróg. Hitlerowskie Niemcy i Polska przeciw Zwiąkowi Radzieckiemu, Warszawa 2013, s. 151.

${ }^{16}$ R. Knoll, Uwagi, s. 12, 13.

${ }^{17}$ Ibidem, s. 15.

${ }^{18}$ Ibidem, s. 9.
} 
„nie ma właściwie żadnej różnicy między agitatorem komunistycznym, a agentem rosyjskim”. Jednak jego zdaniem dla Polski groźniejszą od Rosji sowieckiej byłaby Rosja „prawosławna i nacjonalistyczna". Niezmiennie twierdził, że w interesie Polski pozostaje prowadzenie działań zmierzających w kierunku rozbicia Związku Sowieckiego ,na poszczególne państwa narodowe i to niesfederowane oraz nieskłonne do ścisłych porozumień"19.

W kwestii ukraińskiej Knoll postulował utrzymanie polskiej polityki ukrainofilskiej w odniesieniu do ziem położonych na wschód od granicy Rzeczypospolitej. Podkreślał, że istnienie „samodzielnej Ukrainy leży w naszym [polskim - H. B.] trwałym interesie całkiem niezależnie od sympatii, którą się ma do tego narodu, ani nawet od oceny wartości narodowej danego plemienia" ${ }^{20}$. Jednocześnie dodawał, że tak rozumiana polska polityka wschodnia, której ważnym celem pozostawać powinno zbudowanie między Rzecząpospolitą a Rosją niepodległego państwa ukraińskiego, może być realizowana tylko w ścisłej współpracy ze wszystkimi bezpośrednim sąsiadami Związku Sowieckiego. Nie wykluczał także zainteresowania realizacją idei prometejskiej ,odległych mocarstw”, przy czym nie precyzował, które miał na myśli.

Były poseł w Berlinie wykluczał natomiast możliwość udziału Niemiec w urzeczywistnianiu tej idei, dodając, że to właśnie Trzecia Rzesza była wówczas tym najbardziej zainteresowana. Zakładał, że strona polska mogłaby teoretycznie rozważać możliwość zawarcia umowy z Niemcami dotyczącej rozczłonkowania Związku Sowieckiego. Jednak biorąc pod uwagę potencjał gospodarczy i militarny obydwu państw w końcu lat trzydziestych XX w., „umowa taka — pisał Knoll — byłaby dla nas [Polski — H. B.] niebezpieczna, jej wykonanie wprost groźne, a już współdziałanie bez umowy byłoby krokiem samobójczym". Ten doświadczony polityk i dyplomata trafnie oceniał, że w 1939 r. ,,przemoc niemiecka” skierowana przeciwko Związkowi Sowieckiemu byłaby przede wszystkim niebezpieczna dla Polski ${ }^{21}$.

Roman Knoll był jednym z nielicznych polskich ekspertów w dziedzinie polityki zagranicznej, który na przełomie 1938 i 1939 r. upatrywał zagrożenia bezpieczeństwa i suwerenności Polski głównie ze strony Niemiec. Wydarzenia 1938 r. pod tym względem uważał za wyjątkowo niekorzystne dla Polski. Anschluss Austrii, przyłączenie Sudetów i zwasalizowanie Czechosłowacji znacznie wzmocniło i tak już potężne Niemcy, a zajęcie przez Polskę Zaolzia, jego zdaniem, nie zrównoważyło nawet w najmniejszym stopniu strat, które poniosło państwo polskie wskutek załamania się czechosłowackiego systemu obrony przed naporem niemieckim. Rzeczpospolitą od zachodu i północy, a także od południowego zachodu otaczała wówczas Trzecia Rzesza, którą Knoll oceniał jako „niebywałą w dziejach osiemdziesięciomilionową jednolitą maszynę bojową, puszczoną w ruch, pracującą bez wytchnienia nad rozwinięciem dalszej mocy i osiągnięciem dalszych zdobyczy"22. Jego zdaniem poprawa stosunków polsko-niemieckich po 1933 r. była jedynie iluzją stworzoną przez propagandę hitlerowską, a przychylny ton wobec Polski był potrzebny Berlinowi tylko do rozstrzygnięcia na swoją korzyść innych spraw na arenie międzynarodowej. Knoll uważał, że w rzeczywistości żaden z postulatów wysuwanych przez Polskę po adresem Niemiec nie został po 1933 r. uwzględniony, a pozorna poprawa relacji między obydwoma krajami tylko wprowadzała w błąd polską opinię publiczną.

Ostatnim pytaniem, na które starał się odpowiedzieć autor Uwag o polskiej polityce 1939, było zagadnienie realności zerwania przez hitlerowskie Niemcy współdziałania z Sowietami. Uważał on, że kwestie ustrojowe nie stanowią przeszkody we współpracy między Berlinem

\footnotetext{
${ }^{19}$ Ibidem, s. 18.

${ }^{20}$ Ibidem.

${ }^{21}$ Ibidem, s. 21.

${ }^{22}$ Ibidem, s. 26, 36.
} 
i Moskwą, ,jeżeli tylko interesy obu mocarstw okażą się zbieżne, a zbieżność taka łatwa byłaby do osiągnięcia w sprawie polskiej”23. Realny był, jego zdaniem, nie tylko powrót do polityki Rapallo, ale także szybkie i niespodziewane zawarcie sojuszu między Trzecią Rzeszą i Związkiem Sowieckim, który stanowiłby zagrożenie dla wszystkich niepodległych narodów Europy, a przede wszystkim dla Polski.

Ta ostatnia prognoza Knolla urzeczywistniła się pół roku później, a jej autor w opracowaniach i memorandach, które pisał w warunkach zmienionych wojną i okupacją, powracał do wielu kwestii podniesionych w Uwagach o polskiej polityce $1939^{24}$. Wśród podejmowanych przez niego tematów znalazły się zarówno oceny przeszłości, głównie dotyczące polityki zagranicznej II Rzeczypospolitej, jak i wizje przyszłości odnoszące się do powojennego porządku międzynarodowego oraz kwestii granic i polityki państwa polskiego po zakończeniu wojny. Knoll głównie jednak wypowiadał się w sprawach bieżących, wynikających ze zmieniającej się w wyniku działań wojennych sytuacji międzynarodowej.

Spośród zachowanych tego rodzaju materiałów najwcześniejszy jest list Knolla do szefa dyplomacji rządu RP na wychodźstwie Augusta Zaleskiego z 6 II 1940 r. ${ }^{25}$ Przedmiotem zainteresowania autora była przede wszystkim polska polityka wschodnia. Prosił Zaleskiego o wyjaśnienie wielu kwestii dotyczących działań przedwrześniowych władz Rzeczypospolitej. Interesowała go zwłaszcza odpowiedź na pytanie, dlaczego we wrześniu 1939 r. „nie broniliśmy się przeciwko Sowietom"26. Knoll domagał się od rządu polskiego prowadzenia aktywnej polityki wobec Związku Sowieckiego. Proponował umieszczenie Wydziału Wschodniego MSZ w Stambule i współpracę ,z całym towarzystwem Saabadu, Ukraińcami, całym Prometeuszem i ze Syjonistami”. Doradzał powierzenie kierownictwa tej akcji swojemu dawnemu, bliskiemu współpracownikowi Mieczysławowi Chałupczyńskiemu.

${ }^{23}$ Ibidem, s. 38; M. Kornat, Polska 1939 roku wobec paktu Ribbentrop-Mołotow, Warszawa 2002, s. 234. Twierdzenie autora książki, że Roman Knoll dopuszczał możliwość powrotu do współpracy między Berlinem i Moskwą ,tylko po zmianie ustroju w Niemczech, tj. po załamaniu się narodowego socjalizmu", nie całkiem jest zgodne z myślą tego polityka i dyplomaty zawartą w Uwagach.

${ }^{24}$ Roman Knoll w 1939 r. nie wyjechał z Warszawy za granicę, jak wielu innych polityków i dyplomatów, chociaż mógł to zrobić bez większych trudności zarówno w końcu 1939, jak i na początku 1940 r. dzięki dobrym kontaktom $\mathrm{z}$ Włochami. W tym czasie ułatwił on wyjazd z okupowanej Polski wielu osobom, sam jednak opuścić kraju nie chciał. Od momentu wybuchu wojny wokół Knolla zgromadziła się grupa przyjaciół i dawnych współpracowników z okresu służby dyplomatycznej, która z czasem przekształciła się w tajną inteligencką organizację polityczną Towarzystwo Patriotyczne. Knoll był także doradcą do spraw zagranicznych delegata rządu RP na kraj i utrzymywał kontakty ze swoim przyjacielem i byłym szefem Augustem Zaleskim, który powrócił na stanowisko ministra spraw zagranicznych, tym razem w rządzie polskim na wychodźstwie Władysława Sikorskiego. A. Kaczkowska, Pamięci Romana Knolla, „Kultura”, nr 1-2 (135-136), Paryż 1959, s. 196; W. Bartoszewski, 1859 dni Warszawy, wyd. II, Kraków 1984, s. 224, 225; Dwa memoriaty Romana Knolla (z września 1943 r. oraz z kwietnia 1944 r.) w sprawie ksztattu bieżącej polskiej polityki zagranicznej i jej założeń na okres powojenny, wyd. A. G. Dąbrowski, „Teki Archiwalne" 2011, t. XI(XXXIII), 2011, s. 211; W. Kamieniecki, op. cit., s. 150, 151.

${ }^{25}$ List Knolla do Zaleskiego, 6 II 1940 r., kopia, Archiwum Polskiej Akademii Nauk, Zespół osobowy Witolda Kamienieckiego, 1, k.1; W Kamieniecki, op. cit., s. 151. List jest odpowiedzią na „kartkę” Zaleskiego, którą Knoll otrzymał w połowie grudnia $1939 \mathrm{r}$.

${ }^{26}$ To pytanie nurtowało zarówno Polaków w kraju, jak i na emigracji. Zaniechania popełnione przez władze RP w ostatnich godzinach pobytu na terytorium kraju było przedmiotem surowych ocen historiografii. Przedmiotem surowej krytyki stał się przede wszystkim rozkaz Naczelnego Wodza, marszałka Edwarda Rydza-Śmigłego z 17 IX 1939 r. ,z Sowietami nie walczyć”, ale także dwuznaczne stanowisko Ministerstwa Spraw Zagranicznych w sprawie prawnomiędzynarodowego stanu stosunków polsko-sowieckich po 17 września. M. Kornat, op. cit., s. 522, 523. 
Problemy poruszone w liście Knolla do Zaleskiego, zwłaszcza ukraiński, okazały się dla władz Rzeczypospolitej na wychodźstwie niezwykle aktualne. W ostatnich miesiącach 1939 r. i na początku 1940 r. środowiska ukraińskie wystąpiły wobec polskich placówek dyplomatycznych w Bukareszcie ${ }^{27}$ i Sztokholmie ${ }^{28}$ z różnego rodzaju propozycjami współpracy. W tym czasie sprawą ewentualnego porozumienia rządu RP z przedstawicielami emigracji ukraińskiej zajmował się zarówno Komitet Polityczny Rady Ministrów, jak i Komitet dla Spraw Kraju ${ }^{29}$. Należy zwrócić uwagę także na instrukcję szefa polskiej dyplomacji Augusta Zaleskiego z 13 XI 1939 r. Minister stwierdzał, że zajęcie przez władze RP sprecyzowanego stanowiska w kwestii ukraińskiej jest przedwczesne, ale jednocześnie zlecał placówkom dyplomatycznym podjęcie sondażowych rozmów z różnymi ugrupowaniami ukraińskimi ${ }^{30}$.

$\mathrm{Na}$ początku 1940 r. liczne analizy problemu ukraińskiego powstały w Ministerstwie Informacji i Dokumentacji, w którym opracowywano i gromadzono materiały dotyczące spraw narodowościowych. Głównym ekspertem i autorem wielu memoriałów z tej dziedziny był szef Wydziału Narodowościowego, później przekształconego w Departament Narodowościowy, profesor Olgierd Górka. Koreferaty do tych opracowań najczęściej sporządzał przedwojenny lwowski adwokat, doktor Bogusław Longchamps de Berier. Stanowiska obu ekspertów w sprawie ukraińskiej znacznie różniły się od siebie. Górka uważał, że władze polskie już na początku 1940 r. powinny wydać proklamację o niepodległości Ukrainy i zadeklarować gotowość dokonania po wojnie dość daleko idących zmian wschodniej granicy Rzeczypospolitej, w wyniku czego niektóre terytoria, przed wrześniem 1939 r. należące do Polski, weszłyby w skład przyszłego państwa ukraińskiego. Natomiast Longchamps był przeciwny prowadzeniu wówczas negocjacji z Ukraińcami i wydawaniu przez rząd RP jakichkolwiek proklamacji dotyczących niepodległości państwa ukraińskiego. Jego zdaniem wschodnie granice Rzeczpospolite nie powinny podlegać jakiejkolwiek dyskusji, a niepodległa Ukraina byłaby znacznie niebezpieczniejszym sąsiadem niż Rosja ${ }^{31}$.

${ }^{27}$ Depesza Poselstwa RP w Bukareszcie w sprawie konferencji z Ukraińcami w dniach 10 i 11 I 1940 r., 13 I 1940 r., Instytut Polski i Muzeum gen. Sikorskiego (dalej: IPiMS), PRM-15A/1940, mikrofilm 2, s. 1, 2; Pismo ambasadora RP w Bukareszcie R. Raczyńskiego do gen. W. Sikorskiego ze szczegółowym sprawozdaniem z konferencji polsko-ukraińskiej, 13 I 1940 r., ibidem, s. 3-12. Zob. Polskie Dokumenty Dyplomatyczne 1940 (dalej: PDD 1940), red. M. Hułas, Warszawa 2010, dok. nr 14, s. 20-26; J. J. Bruski, Londyn-Bukareszt-Stambut. Przyczynek do działalności Włodzimierza Bączkowskiego w latach 1939-1940, „Nowy Prometeusz” 2015, nr 5, s. 185, 186.

${ }^{28}$ Depesza Poselstwa RP w Sztokholmie w sprawie utworzenia legionu ukraińskiego, 28 I 1940 r., IPiMS, PRM-15A/1940, mikrofilm 2, s. 13.

${ }^{29}$ Uchwała Komitetu dla Spraw Kraju z 28 XI 1939 r. nie była oficjalną deklaracją rządu RP, lecz tylko — jak określono w jej tytule — instrukcją dla mężów zaufania w sprawie ukraińskiej. Dokument ten przewidywał możliwość utworzenia polsko-ukraińskiego frontu zwróconego przeciwko okupantom, a także powstanie niepodległego państwa ukraińskiego sfederowanego z Rzecząpospolitą na zasadach równości. R. Torzecki, Polacy i Ukraincy. Sprawa ukrainska w czasie II wojny światowej na terenie II Rzeczypospolitej, Warszawa 1993, s. 100, 101.

${ }^{30}$ Instrukcja Zaleskiego do ambasadora w Rzymie Bolesława Wieniawy-Długoszowskiego, 13 XI 1939 r., Archiwum Akt Nowych (dalej: AAN), Archiwum Instytutu Hoovera (dalej: AIH), box 607, folder 15. Identyczne instrukcje otrzymali także ambasadorowie Polski w Londynie i Waszyngtonie. J. J. Bruski, W kręgu spraw prometejskich i ukraińskich. Jerzy Giedroyc w Rumunii 1939-1941, w: Giedroyc i Ukraina. Ukraińska perspektywa Jerzego Giedroycia i środowiska paryskiej „,Kultury”, red. M. Szymczyszyn, M. Zajączkowski, Warszawa-Lublin-Szczecin 2014, s. 74, 75.

${ }^{31}$ Notatka O. Górki dla ministra S. Strońskiego, Uzupełnienie memoriału z 4 II 1940 r. w sprawie ukraińskiej, 23 II 1940 r., IPiMS, PRM-15A/1940, mikrofilm 2, s. 17-23; Uwagi B. Longchampsa 
Jednak szanse na wypracowanie wspólnej polsko-ukraińskiej płaszczyzny porozumienia okazały się trudne ${ }^{32}$. Rozmowa wiceministra spraw zagranicznych Zygmunta Gralińskiego z byłym przewodniczącym Ukraińskiej Najwyższej Rady Emigracyjnej w Paryżu Aleksandrem Szulginem (Ołeksandrem Szułhynem), przeprowadzona 20 II 1940 r., dowiodła, że nawet pozostający dotychczas w dobrych stosunkach z Polską petlurowcy formułowali daleko idące oczekiwania wobec rządu RP, a jednocześnie wykluczali możliwość uznania granicy polskoukraińskiej ustalonej w umowie warszawskiej z 21 IV 1920 r. i zrezygnowania z praw Ukrainy do Małopolski Wschodniej ${ }^{33}$.

W dyskusji nad sprawą Ukrainy zabrał głos także Knoll. Przesłany z Warszawy memoriał został opatrzony datą „,marzec 1940 r.” Knoll, podobnie jak w Uwagach o polskiej polityce 1939, nie ograniczył wypowiedzi tylko do kwestii ukraińskiej, ale głównie na niej skoncentrował swoją uwagę. Myślą przewodnią jego memoriału jest stwierdzenie, że Polska, rozważając problem przyszłości Ukrainy czy Litwy, musi przede wszystkim bronić integralności swojego terytorium. Był przeciwny podejmowaniu w czasie wojny dyskusji o ,wielkiej Ukrainie”, co nie tylko nie przyczyniłoby się do podziału Związku Sowieckiego, ale przyniosłoby osłabienie Polski, Węgier i Rumunii. Stwierdzał, że niepodległa Ukraina powinna „deukrainizować ziemie polskie, rumuńskie i węgierskie, a nie odwrotnie”. Jednocześnie stawiał ważne pytanie: „Któż zaręczy, czy ziemie oddane dziś Ukrainie, nie okażą się jutro znów w ręku Wszechrosji centralistycznej, czy sfederowanej, sowieckiej, czy cesarskiej”. Jednak nie wykluczał możliwości powrotu w warunkach pokojowych do ponownego rozważenia kwestii granic Ukrainy, kiedy ta będzie państwem niepodległym, pozostającym w przyjaznych stosunkach z Polską i Rumunią. Knoll nakłaniał władze RP do zaangażowania się w utworzenie ośrodka zdolnego do podjęcia walki o niepodległą Ukrainę. Uważał, że w tym celu pod auspicjami rządu RP powinna zostać usytuowana w Stambule centrala niepodległościowców ukraińskich, którzy byliby życzliwie ustosunkowani do Polski. Wybór Stambułu uzasadniał szansą na uzyskanie przychylności władz tureckich dla polskich działań. Jego zdaniem umiejscowienie takiego ośrodka w Paryżu czy Londynie oznaczałoby podporządkowanie sprawy ukraińskiej mocarstwom zachodnim. Ponadto Knoll stwierdzał, że „Ukraińcy w Stambule winni być tylko na poły emigrantami”, lecz przede wszystkim „,muszą oni jeździć stale w teren, pracować konspiracyjnie i rewolucyjnie, formować kadry i poddawać się niebezpieczeństwom, nim jeszcze przyjdzie chwila uderzenia"”34.

do Uzupełnienia memoriału prof. Górki z dnia 4 II 1940, 24 II 1940 r., ibidem, s. 24-33; R. Torzecki, op. cit., s. 120, 103, 113.

${ }^{32}$ Notatka członka Komitetu dla Spraw Kraju Aleksandra Ładosia, 2 II 1940 r., PDD 1940, dok. nr 59, s. 101-103. Autor notatki pisał o konieczności zawarcia porozumienia polsko-ukraińskiego „na terenie zagranicznym”. A. Ładoś zwracał uwagę, że podstawową kwestią pozostaje nie tylko ,rozstrzygnięcie zasadniczych problemów merytorycznych" takiego porozumienia, ,ale przede wszystkim znalezienie odpowiedniego partnera do układu, który mógłby być ze strony ukraińskiej uważany za kontrahenta równorzędnego dla Rządu Polskiego w Angers”. Dodawał, że znajdujący się Paryżu petlurowcy z Aleksandrem Szulginem na czele nie są dostateczną reprezentacją polityczną narodu ukraińskiego.

${ }_{33}$ Niepodpisana notatka z rozmowy Gralińskiego z Szulginem, 20 II 1940 r. PDD 1940, dok. nr 92, s. 91-93. Rozmówca Gralińskiego oświadczył, że strona ukraińska oczekuje od władz RP: 1) stwierdzenia, że odbudowa państwa ukraińskiego jest jednym z polskich celów wojennych, 2) formalnego uznania rządu Ukraińskiej Republiki Ludowej, 3) zawarcia z tym rządem układu polityczno-wojskowego, 4) utworzenia legionu ukraińskiego, który podlegałby rządowi petlurowskiemu, a ewentualnie pozostawał pod wspólnym dowództwem polsko-ukraińskim. Minister Graliński zdecydowanie odrzucił możliwość zrzeczenia się przez stronę polską Małopolski Wschodniej. Wykluczył także możliwość tworzenia legionu ukraińskiego złożonego z obywateli polskich narodowości ukraińskiej.

${ }^{34}$ Memoriał R. Knolla dla rządu RR, marzec 1940 r., IPiMS, PRM-15A/1940, mikrofilm 2, s. 54-57. 
Trudno jednoznacznie ocenić, czy opinia Knolla w sprawie Ukrainy była bliższa poglądom Longchampsa czy Górki. Knoll, podobnie jak lwowski adwokat, za sprawę nadrzędną uważał integralność terytorialną Rzeczypospolitej. Jednak, jako prometeista, był zwolennikiem niepodległej Ukrainy. Dlatego też kwestię niepodległości i granic Ukrainy łączył z urzeczywistnianiem idei wyzwalania narodów Kaukazu ${ }^{35}$. Analogicznie jak Longchamps uważał, że stanowisko polskie w kwestii ukraińskiej powinno zostać zakomunikowane Francji i Wielkiej Brytanii z całą stanowczością i oficjalnie oraz ,podane do wiadomości Kraju w sposób absolutnie obowiązujący"36. Sojusznicy natomiast, zdaniem obydwu analityków, stanowisko to powinni respektować.

W memorandum z marca 1940 r. oprócz kwestii ukraińskiej Knoll podniósł także problemy mniejszości białoruskiej i żydowskiej w Polsce oraz sprawę relacji między Polską i Litwą, prezentując poglądy zbliżone do tych, jakie przedstawił wcześniej w Uwagach o polskiej polityce 1939. Kwestionował odrębność narodową Białorusinów, uważając ich za ,ludność przejściową między Polakami a Rosjanami, o gwarze nieco odrębnej”. Stwierdzał, że jeśli uda się wcielić po wojnie Mińsk z okolicami do Rzeczypospolitej i uczynić z tego miasta jedną ze stolic województw litewskich, to wówczas „nazwa Białoruś przybierze charakter podobny do Podlasia, Polesia, czy Huculszczyzny"37.

Knoll, snując rozważania na temat ewentualnych powojennych rozgraniczeń między Rosją, Ukrainą a federacją kaukaską, które mogłyby być zrealizowane jedynie w przypadku urzeczywistnienia jego promteiskich projektów, dodawał jeszcze jedną geopolityczną sugestię: ,a wreszcie Odessa i jej szerokie zaplecze jest najwspanialszym miejscem dla szkicowania ogniska narodowego dla Żydów, bez stworzenia którego konflikt obecny [trwająca wojna - H. B.] nie będzie zakończony trwałym pokojem" "38. Stwierdzał, że prześladowania ludności żydowskiej na ziemiach polskich okupowanych przez Niemcy i ,gwałtowność ruchu żydowskiego na terenach zajętych przez Rosję sowiecką" stworzyły warunki, w których realizowany od około dwudziestu lat narodowy i państwowy projekt środowisk syjonistycznych stał się „,nie jakimś ideałem dalekiej przyszłości, ale koniecznością chwili”, ponieważ „,poruszone żydowskie masy nie mają dokąd, ani po co wracać, a tam gdzie są, nie mogą w spokoju pozostać" ${ }^{39}$. Przewidywał także, że Żydzi w Rumunii, na Węgrzech i na Ukrainie (w przypadku jej desowietyzacji) mogą znaleźć się w analogicznej sytuacji jak ich rodacy w Polsce pod okupacją niemiecką. Dotychczas realizowaną koncepcję budowy państwa żydowskiego na terytorium Palestyny Knoll oceniał krytycznie, twierdząc, że argument ,ziemi praojców” jest niewystarczający, ponieważ jest ona na potrzeby ludności żydowskiej „niewystarczająca, nieurodzajna, daleka od ich europejskich siedzib, klimatem nieodpowiednia", a ponadto stanowiąca zarzewie konfliktu ze ,światem arabskim”. Jednocześnie proponował, aby władze RP aktywnie włączyły się w działania na rzecz utworzenia niepodległego państwa żydowskiego, obstając przy koncepcji usytuowania jego terytorium wokół czarnomorskiej Odessy. Stwierdzał, że pozwoli to Polsce wystąpić z pozytywnym programem w kwestii żydowskiej, a jednocześnie zaowocuje ,żydowską emigracją, prawdziwą, liczną i rzetelną”,

\footnotetext{
${ }^{35}$ Knoll stwierdzał, że granice przyszłej federacji kaukaskiej powinny być wysunięte jak najdalej na północ, możliwie najbliżej Wołgi i Donu. Natomiast Kozaków kubańskich, pomimo ich związków etnicznych z Ukrainą, jego zdaniem należy włączyć do federacji kaukaskiej. Dlatego, nie tylko z powodu zachodniej granicy przyszłego państwa ukraińskiego, ale także ze względu na Kaukaz, Knoll sprzeciwiał się podnoszeniu podczas wojny kwestii „wielkiej Ukrainy”. Ibidem, s. 57, 58.

${ }^{36}$ Ibidem, s. 56.

${ }^{37}$ Ibidem, s. 58, 59

${ }^{38}$ Ibidem, s. 58.

${ }^{39}$ Ibidem, s. 61.
} 
korzystną z punktu widzenia państwa polskiego. Ponadto postulował należyte poinformowanie „wielkiej finansjery żydowskiej Zachodu” o sytuacji Żydów w Europie ŚrodkowoWschodniej, co pozwoliłoby na obudzenie jej solidarności narodowej i współudział w rozwiązywaniu problemu ciężkiego losu rodaków ${ }^{40}$.

Opinię Knolla w sprawie sytuacji ludności żydowskiej w Polsce pod okupacją niemiecką i sowiecką potwierdzają oceny zawarte w innych dokumentach sporządzonych na początku 1940 r. przez przedstawicieli zarówno polskiego państwa podziemnego, jak i władz RP na wychodźstwie. Na podstawie relacji nadesłanych z kraju w Oddziale II Sztabu Naczelnego Wodza powstała notatka sporządzona 7 II 1940 r. przez płk. T. Wasilewskiego zatytułowana Wiadomości o położeniu Żydów w Polsce. Autor przedstawił sytuację ludności żydowskiej kolejno: na ziemiach polskich wcielonych do Niemiec, w Generalnym Gubernatorstwie oraz na ziemiach pozostających pod okupacją sowiecką. Dla położenia ludności żydowskiej na terytoriach wcielonych do Trzeciej Rzeszy używa on określenia „,skrajny terror”. Żydzi na tym obszarze byli pozbawiani majątku i wysiedlani, najczęściej do Generalnego Gubernatorstwa, a handel żydowski przechodził w ręce polskie. Nie lepiej według notatki Wasilewskiego przedstawiała się sytuacja Żydów w Generalnym Gubernatorstwie. Dodaje on, że Niemcy ułatwiali wówczas ludności żydowskiej emigrację na ziemie polskie pozostające pod okupacją sowiecką, gdzie Żydzi byli traktowani przez okupanta lepiej niż Polacy i Ukraińcy. Wasilewski pisze, że takie stwierdzenia znajdują się niemal we wszystkich relacjach z kraju. Ponadto dodaje, że Żydzi, z wyjątkiem „sfer bogatych”, entuzjastycznie powitali okupację sowiecką, czynnie włączając się w tworzenie nowej miejscowej administracji i milicji oraz podjęli współpracę z NKWD, co spowodowało groźby ze strony Polaków i Ukraińców traktowania ich na równi z bolszewikami po wypędzeniu okupantów ${ }^{41}$.

Wiedza o sytuacji ludności żydowskiej w Europie Środkowo-Wschodniej w 1940 r. była dosyć dobra zarówno w Europie Zachodniej, jak i w Stanach Zjednoczonych. Nie była ona także obca organizacjom żydowskim w tych krajach. Wiedziano, że na ziemiach polskich okupowanych przez Trzecią Rzeszę władze niemieckie „,wyzuły Żydów z miast i miasteczek, konfiskując ich przemysł, handel i koncentrując ich w obozach". W tym czasie organizacje syjonistyczne w Stanach Zjednoczonych obawiały się odrodzenia w powojennej Europie antysemityzmu i dlatego zabiegały u władz amerykańskich o stworzenie na przyszłość warunków emigracji dla osiedlenia Żydów ,tak w Palestynie, jak i w pewnych koloniach angielskich, a w szczególności w Kenii”. Podsekretarz stanu USA Adolf August Berle w rozmowie z ambasadorem RP w Waszyngtonie Janem Ciechanowskim stwierdzał, że organizacje te zdają sobie sprawę, że będzie rzeczą niemożliwą, ,aby ludność chrześcijańska np. w Polsce, która obecnie zajęła sklepy i drobny przemysł dawniej uprawiany przez Żydów, przemysł ten znowu po wojnie oddała w ręce żydowskie”, co stworzyłoby „od razu tarcia i przygotowało grunt do antysemityzmu" 42 .

\footnotetext{
${ }^{40}$ Ibidem, s. 61-63.

${ }^{41}$ Notatka płk. T. Wasilewskiego, 7 II 1940 r., IPiMS, PRM-15A/1940, mikrofilm 2, s. 14, 15. Podobne informacje o sytuacji ludności żydowskiej na ziemiach Rzeczypospolitej pod okupacją niemiecką i sowiecką zawiera raport emisariusza rządu polskiego na wychodźstwie Jana Karskiego z 1940 r. Fragment rozdziału IV w raporcie J. Karskiego, 1940 r., reprodukcja oryginału, S. M. Jankowski, Karski. Raporty tajnego emisariusza, Poznań 2010, s. 53-61.

${ }_{42}$ Raport ambasadora w Waszyngtonie J. Ciechanowskiego w sprawie rozmów z podsekretarzem stanu USA A. Berlem w sprawie rozmów o przyszłości Żydów w Europie Wschodniej, 14 IX 1940 r., PDD 1940, dok. nr 388, s. 656, 657. Przytoczony powyżej dokument podważa bardzo subiektywną ocenę memoriału Romana Knolla przedstawioną przez Dariusza Libionkę, autora artykułu poświęconego stanowisku polskiego państwa podziemnego wobec ludności żydowskiej w Polsce. Autor artykułu
} 
Ostatnią część memorandum otwiera konstatacja: „Litwa teraz, czy w przyszłości winna się połączyć z Polską". Knoll w ten sposób powracał do idei federacji. Jednocześnie powątpiewał w realną możliwość połączenia po wojnie obydwu państw. Stwierdzał, że w takiej sytuacji Polska przede wszystkim musi bronić integralności swojego terytorium w granicach sprzed 1 IX 1939 r. i dlatego rząd RP powinien w sprawie przynależności państwowej Wileńszczyzny zająć jednoznaczne stanowisko. Jednak uważał, że nie należy rezygnować z koncepcji federacji, a realizację tego celu trzeba powierzyć stronnictwu złożonemu z Polaków i Litwinów, które powinno zostać powołane do życia na terytorium Litwy ${ }^{43}$.

Opinia Knolla nie mogła mieć wpływu na treść notatki Ministerstwa Spraw Zagranicznych dotyczącej konieczności określenia oficjalnego stanowiska Polski wobec kwestii ukraińskiej przesłanej 20 lutego premierowi Sikorskiemu. Konkluzje w niej zawarte są jednak zbieżne $\mathrm{z}$ treścią memoriału doradcy do spraw zagranicznych delegata rządu RP na kraj. MSZ proponował przyjęcie czteropunktowej płaszczyzny do rozmów w sprawie Ukrainy: 1) rząd polski uznaje prawo narodu ukraińskiego do własnej państwowości i gotów jest popierać te aspiracje na arenie międzynarodowej, 2) uznaje także potrzebę ścisłej współpracy z rządem ukraińskim, a nawet federacji polsko-ukraińskiej, 3) ustalenie przebiegu granicy między Polską i Ukrainą będzie mogło nastąpić po utworzeniu ukraińskiego rządu narodowego i będzie zależeć od stopnia współpracy politycznej obu państw, 4) władze obydwu państw zagwarantują prawa mniejszościowe Polaków na Ukrainie i Ukraińców w Polsce ${ }^{44}$.

Nie należy natomiast wykluczyć, że memoriał Knolla dotarł do Angers przed przygotowaniem instrukcji ministra spraw zagranicznych w sprawie polityki wobec Ukraińców, którą 14 III 1940 r. Zaleski skierował do placówek dyplomatycznych. Szef polskiej dyplomacji, podobnie jak Knoll, sprawę ukraińską zaliczył do pierwszoplanowych zagadnień polskiej polityki zagranicznej. W pierwszej części instrukcji zawarto wnikliwą ocenę ukraińskich środowisk politycznych i ich stosunku do Polski i do Związku Sowieckiego. W drugiej zaś przedstawiono zadania stojące przed polskimi placówkami dyplomatycznymi i tezy stanowiska rządu RP w sprawie Ukrainy. Spośród kwestii zawartych w ostatniej części instrukcji, ujętych w dwunastu punktach, najważniejsze są stwierdzenia o nienaruszalności wschodnich granic Rzeczypospolitej, gotowości strony polskiej do poparcia aspiracji niepodległościowych Ukraińców oraz wzajemnego uzgadniania stanowiska w tej sprawie z Francją i Wielką Brytanią ${ }^{45}$.

Rząd RP z całą powagą potraktował propozycje Romana Knolla, zwłaszcza dotyczące polskiej polityki wschodniej, odnoszące się do spraw prometejskich, w tym także

\footnotetext{
i wydawca załączonych do niego fragmentów dokumentów, opublikowanych w sposób daleki od sztuki edytorskiej (dowolne „przycinanie” dokumentów, brak w wielu miejscach przypisów oraz nieścisłości w przypisach umieszczonych pod tekstem), pisze między innymi, że „rady i zalecenia Knolla, choć polska dyplomacja nie mogła $z$ nich korzystać bez narażania się na niebezpieczeństwo kompromitacji wobec sojuszników, wpisywały się w dyskusję w „kwestii żydowskiej” prowadzoną przez niektóre kręgi polityczne w kraju i na emigracji”. Twierdzenie to nie wytrzymuje konfrontacji z zachowanymi dokumentami dyplomatycznymi. Wówczas nie tylko polscy dyplomaci podejmowali kwestię możliwości realizacji idei migracji ludności żydowskiej po zakończeniu wojny, ale także dyplomaci państw sojuszniczych. Należy dodać, że stosowane przez D. Libionkę określenie „niektóre kręgi” należy uznać za co najmniej zbyt ogólnikowe i każdy historyk takich określeń powinien unikać. D. Libionka, ZWZAK i delegatura rządu wobec eksterminacji Żydów polskich, w: Polacy i Żydzi pod okupacją niemiecka 1939-1945. Studia i materiały, red. A. Żbikowski, Warszawa 2006.

${ }_{43}^{43}$ Memoriał R. Knolla dla rządu RP, marzec 1940 r., s. 64, 65.

${ }_{44}$ Notatka MSZ dla premiera Sikorskiego, 20 II 1940 r., PDD 1940, dok. nr 91, s. 155-158.

${ }_{45}$ Instrukcja Zaleskiego dla polskich placówek dyplomatycznych w sprawie polityki wobec Ukraińców, 14 III 1940 r., PDD 1940, dok. nr 139, s. 232-238.
} 
niepodległości Ukrainy. 4 kwietnia podsekretarz stanu Zygmunt Graliński skierował do placówek dyplomatycznych instrukcję w sprawie polskiej polityki wobec Kaukazu. Działania polskiego resortu spraw zagranicznych $\mathrm{w}$ zakresie kontaktów $\mathrm{z}$ ruchem prometejskim, a zwłaszcza współpraca z Konfederacją Kaukaską, skupiającą niepodległościowe ośrodki polityczne narodów kaukaskich, miały mieć charakter poufny ze względu na stosunek „Francji i Anglii do Sowietów”. Graliński dodawał, że problem kaukaski powinien być rozstrzygnięty przy udziale Turcji. Dalsza część instrukcji zawierała charakterystykę emigracyjnych ośrodków kaukaskich. MSZ RP, które poparło zbliżenie Ormian do Konfederacji Kaukaskiej, jednocześnie doradzało zachowanie ostrożności w stosunku do środowiska ormiańskiego, które dotychczas prowadziło politykę dwulicową, utrzymując „kontakty ze Rosją Sowiecką z jednej strony, a z Włochami i Niemcami z drugiej strony". Instrukcja zalecała placówkom: 1) pomoc organizacjom kaukaskim, 2) obserwowanie i informowanie o stosunku poszczególnych rządów do problemu kaukaskiego, 3) oddziaływanie na przedstawicieli państw sojuszniczych w kierunku wyjaśniania korzyści ze współpracy z kaukaskimi ruchami niepodległościowymi, 4) utrzymywanie współdziałania z przedstawicielami władz tureckich w kwestii kaukaskiej, 5) podtrzymywanie kontaktów z emigracyjnymi organizacjami kaukaskimi ${ }^{46}$.

Kierownictwo polskiego MSZ podzielało opinię Knolla o konieczności współdziałania z Turcją w sprawie Kaukazu i możliwości uzyskania poparcia Ankary dla walki o niepodległość nie tylko narodów kaukaskich, ale także Ukrainy. W pierwszej połowie lutego $1940 \mathrm{r}$. z inicjatywy władz RP dotarł do Stambułu jeden z najwybitniejszych działaczy prometejskich i sowietologów Włodzimierz Bączkowski, który po klęsce wrześniowej był zaangażowany w kontakty ze środowiskami ukraińskimi. Początkowo miał on realizować szerzej zakrojoną akcję prometejską. $Z$ raportu konsula generalnego w Bagdadzie Zygmunta Vetulaniego z 25 I 1940 r. wynika, że z inicjatywy MSZ Bączkowski miał przyjechać wówczas do Iraku w celu prowadzenia na miejscu studiów nad zagadnieniami wschodnimi ${ }^{47}$. Nie zachowały się żadne dokumenty potwierdzające urzeczywistnienie tego projektu. Natomiast dysponujemy protokołem narady, do której doszło 12 II 1940 r. w Stambule, w prywatnym mieszkaniu przywódcy Tatarów krymskich Dżafera Sejdameta. W spotkaniu, oprócz Bączkowskiego i Sejdameta, udział wzięli przywódca Tatarów kazańskich Ayas Ischaki oraz reprezentujący Północny Kaukaz Said Szamil. Uczestnicy narady przyjęli deklarację o konieczności dalszej współpracy Polski, Krymu, Turkiestanu, Idel-Uralu i narodów Północnego Kaukazu. Ustalono, że należy dokonać podziału prac prometejskich na trzy strefy, w których decydujący głos należał będzie do najważniejszych krajów prowadzących lub przygotowujących się do walki z Rosją, czyli do Polski, Finlandii i Turcji. Do strefy szczególnych zainteresowań Rzeczypospolitej zaliczono Białoruś i Ukrainę ${ }^{48}$.

Optymizmu MSZ RP oraz polskich prometeistów Knolla i Bączkowskiego w kwestii możliwości przyciągnięcia Turcji do współpracy w walce ze Związkiem Sowieckim nie podzielał ambasador w Ankarze Michał Sokolnicki. Odpowiadając na instrukcję Zaleskiego z 14 III 1940 r. dotyczącą spraw ukraińskich, szef ankarskiej placówki dyplomatycznej informował 8 kwietnia ministra spraw zagranicznych, że na terenie Turcji nie dostrzegł dotychczas

\footnotetext{
${ }^{46}$ Instrukcja podsekretarza stanu Z. Gralińskiego na temat polskiej polityki wobec Kaukazu, 4 IV 1940 r., PDD 1940, dok. nr 170, s. 286-290.

${ }^{47}$ Raport konsula generalnego w Bagdadzie Z. Vetulaniego do MSZ o polityce Związku Sowieckiego i ruchu prometejskim, 25 I 1940 r., ibidem, dok. nr 37, s. 60-63.

${ }^{48}$ Protokół posiedzenia „kierowniczego” centrum prometejskiego w Stambule, 12 II 1940 r., J. J. Bruski, Londyn-Bukareszt-Stambut, s. 197-199.
} 
„Żadnych śladów, ani ech akcji lub propagandy ukraińskiej”, ponieważ w tym kraju nie było i nie ma ukraińskiej emigracji. Przyczyny takiego stanu rzeczy ambasador w Ankarze upatrywał w przyjaznych, a nawet sprzymierzeńczych stosunkach ze Związkiem Sowieckim. Dodawał, że nawet emigracja kaukaska, duchowo i politycznie o wiele bardziej bliska Turcji, była tolerowana przez władze w Ankarze tylko pod warunkiem ,nieprowadzenia żadnej akcji, ani propagandy politycznej”, a kontakty polskich prometeistów z „tą emigracją obserwowano raczej niechętnie i podejrzliwie".

Jednak dalej Sokolnicki pisał o zmianie, jaka w ostatnich miesiącach zaszła wobec przedstawicieli narodów Kaukazu w wyniku rozluźnienia stosunków sowiecko-tureckich. Stwierdzał, że władze tureckie, zwłaszcza wojskowe, nawiązały poufny kontakt z działaczami kaukaskimi i „snują nawet plany założenia jakiejś centrali polityczno-propagandowej, czy komitetu", które zapewniłyby łączność Turcji z narodami Azerbejdżanu, Kaukazu i Krymu, a nawet z Tatarami nadwołżańskimi. Sokolnicki nie wykluczał, że podobne zmiany mogłyby nastąpić w polityce Turcji wobec Ukrainy, gdyby stosunki ze Związkiem Sowieckim uległy dalszemu zaostrzeniu. Ambasador w Ankarze proponował, aby w przypadku narastania konfliktu sowiecko-tureckiego lub wybuchu wojny władze RP porozumiały się z rządem tureckim w kwestii ukraińskiej49.

W drugim kwartale 1940 r. tematykę prometejską polscy dyplomaci podejmowali także w rozmowach z sojusznikami. Ambasador Edward Raczyński w raporcie na temat stosunków brytyjsko-sowieckich z 9 maja pisze jedynie, że przesyła w załączeniu notatkę z rozmów sekretarza ambasady RP w Londynie Antoniego Balińskiego z referentem spraw sowieckich w MSZ Wielkiej Brytanii Fitzroyem Macleanem. Wynikiem tych kontaktów była konkluzja, że „Anglicy pragną mieć przygotowany przeciw Rosji grunt na Bliskim Wschodzie" ${ }^{50}$. W notatce noszącej tę samą datę Baliński stwierdza, że Maclean w sprawach krajów zakaukaskich wykazał bardzo realistyczne podejście. Dyplomata brytyjski oświadczył, że interesują go tylko te organizacje i ci politycy, którzy utrzymują kontakt ze swoim krajem. Ponadto uważał, że ośrodki emigracyjne pragną jedynie zdobyć dla siebie nowe źródła dochodu, a po dwudziestoletniej nieobecności w kraju nie mają z nim żadnego związku ${ }^{51}$.

Klęska Francji i przeniesienie władz RP na wychodźstwie do Wielkiej Brytanii nie pozostało bez wpływu na polską politykę wschodnią. Dotyczyło to także stanowiska Polski wobec ukraińskich i kaukaskich środowisk emigracyjnych. 22 VI 1940 r. gen. Władysław Sikorski depeszował do attaché wojskowego w Rumunii: „Z racji zmiany polityki sowieckiej zażądałem innego kursu ze strony Rosji. Rezultat pozytywny. Wszelkie posunięcia idące na rozbicie Rosji wykluczone" ${ }^{52}$. Oświadczenie jest mało czytelne. Nie wiemy, jaką drogą premier zażądał zmiany kursu ze strony Rosji i jakie były tego pozytywne rezultaty. Odmienny stosunek do ruchu prometejskiego miał wówczas minister Zaleski. Szef polskiej dyplomacji 5 października skierował do ministra skarbu Henryka Strasburgera pismo w sprawie finansowania ruchu prometejskiego, w którym pisał, że byłoby błędem przerwać akcję rozpoczętą w 1919 r. i kontynuowaną przez wszystkie polskie rządy do okresu Angers włącznie, niezależnie od ich zabarwienia politycznego. Zdaniem Zaleskiego nie chodziło wówczas już

\footnotetext{
${ }^{49}$ Raport Sokolnickiego dla Zaleskiego, 8 IV 1940 r., IPiMS, PRM-15A/1940, mikrofilm 2, s. 67-69.

${ }^{50}$ Raport ambasadora RP w Londynie na temat stosunków polsko-brytyjskich, 9 V 1940 r., PDD 1940, dok. nr 217, s. 374-376.

${ }^{51}$ Notatka z rozmów sekretarza ambasady RP w Londynie, 9 V 1940 r., PDD 1940, dok. nr 218, s. 376, 377.

${ }^{52}$ Depesza premiera W. Sikorskiego do attaché wojskowego w Bukareszcie w sprawie polityki polskiej wobec Związku Sowieckiego, 22 VI 1940 r., PDD 1940, dok. nr 287, s. 467.
} 
o prowadzenie aktywnej walki z Sowietami, ale o zakonserwowanie ruchu prometejskiego do czasu, kiedy mógłby zostać z pożytkiem rozwinięty ${ }^{53}$.

Kolejne dwa memoriały w sprawie bieżącej polskiej polityki zagranicznej i jej założeń na okres powojenny zostały przygotowane przez Knolla i zachowały się opatrzone datą wrzesień 1943 r. Ich autor kierował wówczas istniejącą od prawie pół roku samodzielną Sekcją Spraw Zagranicznych Delegatury Rządu RP na Kraj, działającą na prawach departamentu ${ }^{54}$. Pierwszy z tych dokumentów zachował się w postaci szczątkowej jako niekompletny, bez zakończenia, zapis stenograficzny wystąpienia Knolla ${ }^{55}$. Zawarte w nim oceny polityki zagranicznej II Rzeczypospolitej w zasadzie nie różnią się od tych, które zostały sformułowane w Uwagach o polskiej polityce 193956. Najpoważniejszy zarzut, jaki czynił Knoll zarówno dowództwu wojskowemu, jak i ministrowi Józefowi Beckowi, to nieliczenie się z możliwością wojny z Niemcami. Jednocześnie podkreślał, że dążenie ostatniego szefa polskiej

${ }^{53}$ Pismo A. Zaleskiego do ministra skarbu rządu RP, 5 X 1940 r., PDD 1940, dok. nr 413, s. 702, 703.

${ }^{54}$ Inicjatorem utworzenia Departamentu Spraw Zagranicznych Delegatury Rządu RP na Kraj był premier, generał Władysław Sikorski. Kwestia ta była najprawdopodobniej przedmiotem posiedzenia rządu RP na uchodźstwie 11 I 1943 r., kiedy to minister spraw zagranicznych Edward Raczyński referował wniosek MSZ w sprawie przygotowania kadr polskiej służby zagranicznej na okres po zakończeniu wojny. Tekst tego wniosku nie zachował się w zbiorach Instytutu Polskiego i Muzeum gen. Sikorskiego w Londynie. Protokoły posiedzeń Rady Ministrów Rzeczypospolitej Polskiej, t. V: wrzesień 1942-lipiec 1943, red. M. Zgórniak, oprac. W. Rojek, przy współpr. S. Suchcitza, Kraków 2001, dok. nr 150, s. 146-148. Polecenie zorganizowania Sekcji Spraw Zagranicznych w Delegaturze Rządu RP przywiózł emisariusz rządu Jerzy Lerski ps. „Jur”, który przybył do kraju w końcu lutego 1943 r. W marcu tegoż roku powiadomił o decyzji delegata rządu Jana Stanisława Jankowskiego i wręczył Konllowi nominację na dyrektora sekcji. J. Lerski, Emisariusz „Jur”, Warszawa 1989, s. 72, 90, 102. W kwietniu-maju 1943 r. została zorganizowana dwudziestosiedmioosobowa Sekcja Spraw Zagranicznych o kryptonimie „Moc”, której powierzono zadanie przeszkolenia i przygotowania w kraju na okres powojenny kadry pracowników dyplomacji. W. Michowicz, Organizacja slużby dyplomatycznej w okresie II wojny światowej, w: Historia dyplomacji polskiej, t. V: 1939-1945, red. W. Michowicz, Warszawa 1999, s. 93-97; A. Leśniewski, Departament Spraw Zagranicznych - kryptonim „Moc”, 630/Z - Delegatury Rzadu RP na Kraj, w: Władze RP na obczyźnie podczas II wojny światowej, red. Z. Błażyński, Londyn 1994, s. 624-635. Leśniewski stara się udowodnić tezę, że intencją rządu RP było utworzenie departamentu, a nie sekcji, i tylko względy bezpieczeństwa zadecydowały, że Departament Spraw Zagranicznych Delegatury nosił nazwę sekcja, natomiast miała ona wszelkie atrybuty i uprawnienia tak samo jak pozostałe departamenty Delegatury. Po złożeniu niniejszego artykułu do druku ukazała się praca Waldemara Grabowskiego poświęcona „Mocy”. W. Grabowski, Kryptonim Moc. Sekcja Spraw Zagranicznych Delegatury Rzadu RP na Kraj, Warszawa 2015.

${ }_{55}$ Jest to najprawdopodobniej zapis stenograficzny referatu Knolla wygłoszonego na posiedzeniu Komitetu Politycznego Delegatury Rządu RP na Kraj. Archiwum Akt Nowych (dalej: AAN), Armia Krajowa 1942-1945, cz. II, sygn. robocza VII/8, s. 1-10. Dokument ten wydał drukiem Adam Grzegorz Dąbrowski, Dwa memoriaty..., s. 214-236 (dok. nr 1).

${ }^{56}$ Knoll trafnie oceniał, że „głównym motorem” polskiej polityki zagranicznej w całym dwudziestoleciu międzywojennym był Józef Piłsudski, także wtedy, gdy nie był u władzy, a nawet wówczas, kiedy go zabrakło. Piłsudski, co podkreślał autor memoriału, uważał, że Rzeczpospolita „,na stałą i skuteczną pomoc państw zachodnich nie może liczyć. Dlatego, zdaniem marszałka, państwo polskie musi przede wszystkim układać stosunki z sąsiadami. Uważał, że w tym zakresie kwestią najważniejszą jest niedopuszczenie do współpracy niemiecko-rosyjskiej skierowanej przeciwko Polsce. O ile koncepcję polskiej polityki zagranicznej Piłsudskiego i jej realizację do 1935 r. Knoll oceniał pozytywnie, o tyle działania Józefa Becka w tym zakresie zdecydowanie krytykował. Stwierdzał, że ,polityka [zagraniczna J.] Becka [...] była oparta na wytrwałym dążeniu do porozumienia z Niemcami i na chęci odsunięcia jak najdalej Rosji”. Ibidem, dok. nr 1, s. 221-227. 
dyplomacji II Rzeczypospolitej do dobrych stosunków z Niemcami było użyteczne, ale nie należało tego czynić kosztem ustępstw w kwestiach zasadniczych na rzecz Trzeciej Rzeszy. Ponadto zarzucał Beckowi brak konsekwencji w polityce wobec Niemiec ${ }^{57}$.

W drugiej części memoriału Knoll podjął próbę sformułowania zasad powojennej polityki zagranicznej Rzeczypospolitej. Za kwestię fundamentalną w tym zakresie uznał sprecyzowanie zasięgu terytorialnego powojennego państwa polskiego. Uważał, że Polska powinna zajmować obszar między Odrą a Niemnem, ponieważ „może istnieć tylko jako wielkie mocarstwo - z odpowiednią ludnością i terytorium", ale nie sprecyzował przebiegu linii granicznej. Opowiadał się za poszerzeniem terytorium państwa polskiego kosztem Niemiec, lecz w stopniu umiarkowanym. Nie precyzował, jakie obszary, oprócz Prus Wschodnich, powinny zostać przyłączone do Polski. W odniesieniu do polskiej granicy wschodniej stwierdzał, że „maksimum tego, do czego możemy aspirować i do czego musimy aspirować, to jest granica z 1939 r." Opowiadał się za utrzymaniem po zakończeniu wojny pokojowych, dobrych stosunków za Związkiem Sowieckim. Osiągnięcie tego celu uważał za możliwe tylko wówczas, kiedy w Europie Środkowej zostaną stworzone warunki uniemożliwiające ponowne porozumienie między Moskwą i Berlinem. Jednocześnie Polska powinna dążyć do osłabienia pozycji Niemiec w Europie, co zdaniem Knolla byłoby możliwe przy wsparciu Stanów Zjednoczonych i Wielkiej Brytanii. Szef Sekcji Spraw Zagranicznych Delegatury Rządu RP na Kraj nie wykluczał możliwości zbudowania federacji państw środkowoeuropejskich, którą tworzyłyby Polska, Czechosłowacja, Litwa, Węgry i Rumunia ${ }^{58}$.

Drugi z memoriałów z września 1943 r. Uwagi o naszej polityce międzynarodowej został skierowany do rządu RP na uchodźstwie. Knoll, formułując oceny i wysuwając propozycje dotyczące polskiej polityki zagranicznej, nie tylko przedstawiał własne opinie, ale też często zabierał głos „,w imieniu Kraju”. Zapewne miało to przekonać czytelników tego dokumentu, że nie prezentuje jedynie swoich osądów, ale przekazuje również stanowisko władz polskiego państwa podziemnego. Memoriał ten, podobnie jak poprzedni, otwierała krytyczna ocena polskiej polityki zagranicznej w przededniu wybuchu drugiej wojny światowej. Kwestia powojennych granic państwa polskiego została potraktowana równie ogólnikowo jak w opracowaniu skierowanym do polityków krajowych. W odniesieniu do polskiej granicy wschodniej Knoll powątpiewał tym razem nawet w możliwość powrotu do status quo z września $1939 \mathrm{r}$. Jednocześnie dodawał, że szczytem dążeń strony polskiej nie musi być jedynie „odzyskanie przedwojennych granic", i snuł, jak na drugą połowę 1943 r., dosyć fantastyczne rozważania o przyłączeniu do Rzeczypospolitej Mińska i Kamieńca Podolskiego. Jego zdaniem w sprawie granicy z Niemcami w kraju oczekiwano przyłączenia do Polski Śląska Opolskiego, Prus Wschodnich i Gdańska, ewentualnie także części Dolnego Śląska oraz rozszerzenia dostępu do Morza Bałtyckiego.

Za najważniejsze z zadań polskiej polityki zagranicznej Knoll uważał „najściślejsze współdziałanie $\mathrm{z}$ mocarstwami anglosaskimi i to zarówno w prowadzeniu i ukończeniu wojny, jak i w planowaniu organizacji pokoju" "59. Pisząc o kwestii rosyjskiej, stwierdzał, że „imperium sowieckie było, jest i pozostanie naszym wrogiem”, i dodawał: „Obecny ustrój sowiecki daje Rosji większe jeszcze możliwości napastnicze, niźli posiadał ustrój carski, a to

\footnotetext{
${ }^{57}$ Ibidem, dok. nr 1, s. 228, 229.

${ }^{58}$ Ibidem, s. 230-236.

${ }^{59}$ Uwagi o naszej polityce międzynarodowej, wrzesień 1943 r., IPiMS, A 12 73/11, s. 19, 20. 135; D. Libionka, op. cit., s. 132. Autor podaje datę przesłania memoriału do Londynu - sierpień $1943 \mathrm{r}$. Natomiast na dokumencie (maszynopis) widnieje rękopiśmienna zapiska: „we wrześniu 1943 r. przez Romana Knolla".
} 
zarówno dzięki bezwzględności metod najazdu i eksterminacji, jak i przede wszystkim dzięki parawanowi ideologii międzynarodowego komunizmu". Dlatego opowiadał się za zatrzymaniem Rosji na linii polskiej granicy wschodniej według stanu sprzed września 1939 r., ponieważ wkroczenie wojsk sowieckich na terytorium Rzeczypospolitej oznaczałoby utratę suwerenności państwa polskiego ${ }^{60}$. W opinii Knolla ważnym celem polskiej polityki wschodniej powinno pozostawać dążenie do rozbicia Związku Sowieckiego na wiele niepodległych państw narodowych, co dałoby Polsce pełne bezpieczeństwo od wschodu. Jednak zdawał sobie sprawę, że urzeczywistnienie ,tych dążeń może okazać się w chwili likwidacji obecnej wojny nieaktualne"'61.

Mało realistyczne były ówczesne rozważania Knolla na temat Litwy i Ukrainy. Tę pierwszą widział sfederowaną z Polską lub nawet włączoną w granice Rzeczypospolitej jako kraj mający szeroką autonomię. W kwestii ukraińskiej w zasadzie powtórzył tezy zawarte w memoriale z marca 1940 r., opowiadając się za utworzeniem niepodległego państwa ukraińskiego, ale położonego na wschód od przedwojennej granicy Rzeczypospolitej. Podkreślał, że Polska nie może swoich ziem wschodnich poświęcić „,dla niepewnej gry przyszłej antyrosyjskiej polityki”62. Natomiast za trafne należy uznać stwierdzenia Knolla dotyczące koncepcji federacji środkowoeuropejskiej. Uważał, że zwarty polityczny, gospodarczy i militarny blok złożony z kilku czy kilkunastu państw położonych między Rosją a Niemcami okaże się trwały i wartościowy tylko wówczas, jeśli będzie on „owocem długoletniego wysiłku zainteresowanych narodów, rzeczywistego zbliżenia i wzajemnego zrozumienia wchodzących w grę społeczeństw”63.

W dokumencie tym Knoll podjął także ,,sprawę żydowską”. Uważał on, że władze polskie powinny zająć aktywną postawę w kwestii powojennych losów ludności żydowskiej. Według jego oceny pomimo prowadzonej przez Niemcy eksterminacji Żydów około 2 mln spośród nich po zakończeniu wojny znajdzie się w Polsce. Szef Sekcji Spraw Zagranicznych Delegatury Rządu RP na Kraj przewidywał, że powrót ocalałych Żydów może doprowadzić do konfliktu z ludnością polską. Po pierwsze, dlatego, że pomimo „chrześcijańskiego współczucia dla katowanych Żydów" na ziemiach wschodnich Rzeczypospolitej utrzymuje się „ostre rozdrażnienie w stosunku do Żydów, pozostałe z czasów okupacji bolszewickiej”, a po drugie, w całym kraju istnieje taki „stan rzeczy, w którym powrót Żydów do ich placówek i warsztatów jest zupełnie wykluczony". Zdaniem Knolla powrót ten zostałby przez ludność nieżydowską odczytany „nie jako restytucja, ale jako inwazja, przeciwko której broniłaby się ona nawet drogą fizyczną", co z kolei spowodowałby niekorzystne skutki dla polskiej polityki zagranicznej. Uważał, że Polska mogłaby być w tej sytuacji oskarżana przez międzynarodową opinię publiczną o antysemityzm podczas ustalania jej powojennych granic, ubiegania się o kredyty, zawierania sojuszy czy federacji. Dlatego postulował podjęcie przez rząd RP akcji dyplomatycznej zmierzającej do utworzenia państwa żydowskiego na bliżej nieokreślonym ,terytorium wschodnioeuropejskim”. Powrócił tym samym do idei zawartej w memoriale z marca 1940 r., jednak w sierpniu-wrześniu 1943 r. nie precyzował już obszaru, na którym państwo to miałoby powstać i w jaki sposób zostałby on wydzielony ${ }^{64}$.

\footnotetext{
${ }^{60}$ Ibidem, s. 22.

${ }^{61}$ Ibidem, s. 23.

${ }^{62}$ Ibidem, s. 25.

${ }^{63}$ Ibidem, s. 25, 26.
}

${ }^{64}$ Ibidem, s. 26, 27; D. Libionka, op. cit., s. 132, 133. Autor stwierdza, że stanowisko zawarte memoriale R. Knolla było niezgodne z duchem Deklaracji czterech stronnictw podpisanej 15 VIII $1943 \mathrm{r}$. przez Stronnictwo Narodowe, Polską Partię Socjalistyczną, Stronnictwo Ludowe i Stronnictwo Pracy, mówiącej o tym, że problemy mniejszości narodowych zostaną po wojnie uregulowane „na zasadzie tradycji wolności oraz równości praw i obowiązków". Z tezą tą trudno się nie zgodzić, jednak 
Ponad pół roku później, w szybko zmieniającej się sytuacji militarnej (zwłaszcza na froncie wschodnim) i międzynarodowej, Roman Knoll opracował kolejny dokument dotyczący polskiej polityki zagranicznej ${ }^{65}$. Zachował się projekt (pierwopis) tego memoriału datowany na kwiecień 1944 r. Jest to maszynopis z licznymi uzupełnienia i poprawkami oraz skreśleniami dokonanymi ręką autora ${ }^{66}$. Między wrześniem 1943 r. a kwietniem 1944 r. znacznie poszerzyła się wiedza Knolla nie tylko o rosnącej pozycji Związku Sowieckiego w koalicji, ale także na temat nieprzychylnego stanowiska rządu brytyjskiego wobec ustanowienia powojennej wschodniej granicy Polski wzdłuż linii sprzed września 1939 r. W kwietniu 1944 r. do rąk szefa Sekcji Spraw Zagranicznych Delegatury dotarł także raport Jana Karskiego z podróży do Stanów Zjednoczonych i z przeprowadzonej przez niego rozmowy z prezydentem Franklinem Delano Rooseveltem, który wprawdzie deklarował poparcie dla polskich żądań dotyczących powojennych granic Rzeczypospolitej, ale jednocześnie rozważał możliwość korekty wschodniej granicy na korzyść Związku Sowieckiego. Karski pesymistycznie oceniał możliwości anglosaskich sojuszników wpływania na sytuację w Polsce po wykroczeniu na jej terytorium oddziałów Armii Czerwonej. W swoim raporcie wyrażał obawy, którymi dzielił się z Rooseveltem, o przyszłość polskiego państwa podziemnego, gdy nad Wisłą pojawią się formacje NKWD ${ }^{67}$. Czytając opracowany przez Karskiego dokument, Knoll wiedział również o dokonywanych przez wojska sowieckie aresztowaniach na Wołyniu, o rozbrajaniu oddziałów AK, o represjach wobec każdego, kto przyznawał się do polskości, współpracy z rządem RP na wychodźstwie i jego Delegaturą na Kraj lub wykonywania ich rozkazów. Dlatego w memoriale z kwietnia 1944 r. uznał za konieczne „osiągnięcie jakiegoś modus

należy uwzględnić fakt, że z jednej strony Knoll tylko relacjonuje położenie ludności żydowskiej na ziemiach Rzeczypospolitej pod okupacją niemiecką, a z drugiej jego propozycje autorskie dotyczące tworzenia państwa żydowskiego nie są całkowicie obce innym środowiskom politycznym, w tym także żydowskim. Krytycznie o memoriale Knolla z sierpnia-września 1943 r. pisze inny badacz problematyki żydowskiej Dariusz Stola, podkreślając szczególnie gwałtowną reakcję na treść fragmentu tego dokumentu dotyczącą kwestii żydowskiej ze strony żydowskiego przedstawiciela w Radzie Narodowej RP Ignacego Schwarzbarta i bliżej nieokreślonych „Żydów w Ameryce”. Dodaje także, iż w sprawie memoriału trzeba było wysyłać do Waszyngtonu dementi, przeczące, jakoby dokument ten pochodził z Delegatury, a dla zaniepokojonych Brytyjczyków wymyślono nawet nową jego genezę. Autor nie wyjaśnia jednak, po pierwsze, na jakim szczeblu była prowadzona korespondencja między stroną polska i amerykańską, i co było jej przedmiotem oraz, po drugie, dlaczego to urzędnik MSW Olgierd Górka, a nie przedstawiciel polskiego MSZ, ,uspokajał” Foreign Office w kwestii memoriału Knolla. D. Stola, Nadzieja i zagłada. Ignacy Schwarzbart - żydowski przedstawiciel w Radzie Narodowej RP (19401945), Warszawa 1995, s. 229, 230. Obydwaj autorzy, zarówno D. Libionka, jak D. Stola, analizując niewielkie fragmenty obydwu memoriałów Knolla dotyczące kwestii żydowskiej, nie zadali sobie trudu, aby chociaż w przypisach ogólnie wspomnieć o zasadniczym przedmiocie memoriałów R. Knolla, z marca 1940 r. i sierpnia-września 1943 r.

${ }^{65}$ A. Leśniewski, Memoriat ministra Romana Knolla z 1944 roku, w: Materiały do dziejów polskiego uchodźstwa niepodległościowego 1939-1990, uzupełnienia do tomów I, II, V, VI, red. Z. Błażyński, Londyn 1996, s. 94, 95; Dwa memoriaty..., s. 215, 216.

${ }^{66}$ Projekt (pierwopis) memoriału R. Knolla o bieżących kierunkach polskiej polityki zagranicznej oraz jej założeniach na okres powojenny, kwiecień 1944 r., AAN, Delegatura Rządu RP na Kraj1940-1945, 200/XIV/9, s. 72-76. Dokument ten opublikował A.G. Dąbrowski, Dwa memoriały..., dok. nr 2, s. 237245.

${ }^{67}$ S. M. Jankowski, op. cit., s. 351, 365-370, 442, 443. Raport J. Karskiego dostarczył do kraju kurier Ministerstwa Spraw Wewnętrznych Henryk Waniek ps. „Pływak”, który został zrzucony na spadochronie w nocy z 9 na 10 IV 1944 r. nad placówką odbiorczą AK o kryptonimie „Imbryk”, położoną piętnaście kilometrów na północny zachód od Tłuszcza w powiecie radzymińskim. 
vivendi z Sowietami”68. Tym razem wykluczał także możliwość prowadzenia walki zbrojnej w obronie granicy ryskiej. Pomimo wiedzy, jaką miał na temat stanowiska brytyjskiego w kwestii powojennej granicy polsko-sowieckiej, sprecyzowanego w mowie premiera Winstona Spencera Churchilla wygłoszonej w Izbie Gmin 22 II 1944 r. ${ }^{69}$, uważał, że porozumienie musi być osiągnięte za pośrednictwem Anglosasów. Jego zdaniem próba bezpośredniego dialogu ze Moskwą groziłaby państwu polskiemu „utratą wszelkich widoków na utrzymanie niezależności'’70.

Knoll sprecyzował linię polityczną, jaką powinien przyjąć rząd RP przy próbie wznowienia stosunków ze Związkiem Sowieckim i negocjowaniu sprawy polskiej granicy wschodniej oraz ustalaniu warunków dotyczących przejmowania administracji przez władze polskie na ziemiach wyzwalanych spod okupacji niemieckiej. Stwierdzał, że Polska musi porzucić bezkompromisowe stanowisko w kwestii powrotu do granicy ryskiej, a jednocześnie stać na stanowisku ostatecznego ustalenia zasięgu terytorialnego Rzeczypospolitej na wschodzie dopiero w ramach uregulowań pokojowych w Europie po zakończeniu wojny. Natomiast rząd RP na wychodźstwie powinien zgodzić się na wytyczenie, w porozumieniu z mocarstwami anglosaskimi, linii demarkacyjnej, od której na zachód władze RP przystąpią samodzielnie do ustanawiania administracji polskiej. Proponował, aby terytorium położone na wschód od linii demarkacyjnej, zbliżonej do tzw. linii Curzona, było administrowane przez międzysojuszniczy zarząd wojskowy. Obszar między granicą ryską a linią demarkacyjną podlegałby międzysojuszniczemu zarządowi wojskowemu, a o jego przynależności państwowej miałby zadecydować plebiscyt przeprowadzony po wojnie. Uważał, że wobec ultymatywnego stanowiska rządu sowieckiego uniemożliwiającego nawiązanie polsko-sowieckich stosunków dyplomatycznych rząd RP musi zwrócić się do rządów państw anglosaskich z prośbą o pośredniczenie w ustalaniu zasad współdziałania między wojskiem polskim i sowieckim oraz o ustanowienie alianckich misji wojskowych zarówno przy dowództwie wojsk sowieckich wkraczających do Polski, jak i przy dowództwie Armii Krajowej. Ponadto proponował, aby strona polska domagała się zaniechania przeciwstawiania przez stronę sowiecką Związku Patriotów Polskich w Moskwie legalnym władzom RP. Wysuwał też postulat, aby polskie formacje wojskowe tworzone przy armii sowieckiej po ich wkroczeniu na terytorium Rzeczypospolitej zostały podporządkowane dowództwu Armii Krajowej ${ }^{71}$.

Szef Sekcji Spraw Zagranicznych Delegatury uważał, że ostateczne założenia polskiej polityki wschodniej powinny ustalać jedynie władze RP na uchodźstwie, dlatego opowiadał się za zmianą kategorycznego tonu wypowiedzi przedstawicielstwa politycznego kraju, dając przykład deklaracji Rady Jedności Narodowej z 15 III 1944 r. ${ }^{72}$ W porozumieniu

\footnotetext{
${ }^{68}$ Dwa memoriaty..., dok. nr 2, s. 238.

${ }^{69}$ Churchill, przemawiając w Izbie Gmin, oświadczył: „W tym miejscu chciałbym przypomnieć Izbie, że my nigdy nie udzieliliśmy Polsce w imieniu Rządu Jego Królewskiej Mości gwarancji w odniesieniu do jakiejkolwiek szczególnej linii granicznej. Nie pochwalaliśmy zajęcia Wilna przez Polskę w $1920 \mathrm{r}$. Stanowisko brytyjskie w 1919 r. znalazło wyraz w tzw. linii Curzona, która usiłowała rozwiązać ten problem przynajmniej częściowo". Churchill popełnił w tym miejscu błąd. Linia Curzona pojawiła się dopiero w 1920 r. J. Tebinka, Polityka brytyjska wobec problemu granicy polsko-radzieckiej 19391945, Warszawa 1998, s. 330, 331.

${ }^{70}$ Dwa memoriaty..., dok. nr 2, s. 238.

71 Ibidem, s. 239-242.

72 Deklaracja programowa Rady Jedności Narodowej O co walczy naród polski, ogłoszona 15 III 1944 r., w kwestii polskiej polityki zagranicznej stwierdzała, że powojenne państwo polskie oprze się na ścisłym sojuszu z Wielką Brytanią, Stanami Zjednoczonymi, Francją, Turcją i innymi krajami sprzymierzonymi. Na tych samych zasadach RJN deklarowała ułożenie stosunków ze Związkiem Sowieckim, pod warunkiem uznania przez niego integralności granic Rzeczypospolitej sprzed września 1939 r.
} 
ze Związkiem Sowieckim widział szansę na skuteczne przystąpienie do walki z Niemcami i ocalenie niezależnego bytu państwa polskiego. Niezbędne, w jego ocenie, było podjęcie przez Polskę, w uzgodnieniu z Anglosasami, rozprawy zbrojnej z Niemcami w momencie zbliżania się wojsk sowieckich, niezależnie od tego, czy zdoła się osiągnąć porozumienie z Moskwą. Sądził, że tym czasie do kraju powinien powrócić prezydent i rząd, a ujawnienie się władz polskich w momencie załamywania się okupacji niemieckiej może powstrzymać zaborcze zamiary Sowietów. Dopuszczał jednak możliwość okupacji Polski przez Rosję i w takiej sytuacji proponował zaprzestanie działalności ówczesnego państwa podziemnego, a w jego miejsce tworzenie nowych konspiracyjnych komórek cywilnych i wojskowych ${ }^{73}$.

Głos Knolla nie był całkowicie odosobniony. W tym czasie w kierownictwie polskiego państwa podziemnego pojawiały się projekty dotyczące konieczności podjęcia próby porozumienia się ze Związkiem Sowieckim. Opinie takie wyrażali między innymi szef Oddziału II Informacyjno-Wywiadowczego Komendy Głównej Armii Krajowej ppłk Marian Drobik, szef Oddziału III Operacyjnego KG AK gen. Stanisław Tatar, szef Oddziału V Dowodzenia i Łączności KG AK płk Kazimierz Pluta-Czachowski, kierownik Szefostwa Biur Wojskowych KG AK ppłk Ludwik Muzyczka, płk Jerzy Kirchmayer, ppłk Franciszek Herman oraz pracownicy Biura Informacji i Propagandy KG AK Jerzy Makowiecki i Ludwik Widerszal $^{74}$. Propozycje Knolla dotyczące rewizji polskiej polityki wschodniej i podjęcia próby nawiązania współdziałania z Sowietami były zbieżne z tezami sporządzonego kilka miesięcy wcześniej, 7 XI 1943 r., memoriału ppłk. Mariana Drobika, który z tytułu zajmowanego w KG AK stanowiska dysponował znacznie szerszą i uzyskiwaną wcześniej niż szef Sekcji Spraw Zagranicznych Delegatury wiedzą nie tylko na temat sytuacji militarnej na froncie wschodnim, ale także w kwestii polityki mocarstw anglosaskich ${ }^{75}$. Jednak Knoll, Drobik i inni zwolennicy porozumienia z Moskwą kosztem ustępstw terytorialnych na rzecz Związku Sowieckiego, nie mieli poparcia kierownictwa polskiego państwa podziemnego, podobnie jak i premier Stanisław Mikołajczyk, który pod presją Churchilla w pierwszych miesiącach 1944 r. był gotów rozważyć zaakceptowanie tzw. linii Curzona jako wschodniej granicy Polski $^{76}$. Jan Stanisław Jankowski miał uznać dzień, w którym otrzymał memoriał Knolla,

i nieingerowania w wewnętrzne sprawy Polski. W sprawie granic postulowała włączenie w obszar państwa polskiego Prus Wschodnich, Gdańska, klina pomorskiego między Bałtykiem i ujściem Odry a Notecią, ziem między Notecią a Wartą oraz Śląska Opolskiego. Ponadto domagała się wytyczenia granicy z Czechosłowacją zgodnie z porozumieniem z listopada 1918 r. O co walczy naród polski. Deklaracja Rady Jedności Narodowej, Warszawa 1944, passim.

${ }^{73}$ Dwa memoriaty..., dok. nr 2, s. 243-245.

${ }^{74}$ W. Bułhak, Raport szefa Oddziału II KG AK pptk. dypl. Mariana Drobika „,Bieżaca polityka polska a rzeczywistość" i sprawa jego aresztowania (listopad-grudzień 1943), w: Wywiad i kontrwywiad Armii Krajowej, red. W. Bułhak, Warszawa 2008, s. 25-28; A. Zahorski, Ludwik Widerszal (1909-1944), w: Historycy warszawscy ostatnich dwóch stuleci, Warszawa 1986, s. 489, 490; A. Gieysztor, Makowiecki Jerzy, pseud. Mirewicz, Tomasz, Malicki, Wokulski, Kuncewicz (1890-1944), Polski słownik biograficzny, t. XIX, Wrocław-Warszawa-Kraków-Gdańsk 1974, s. 224, 225.

${ }_{75}$ Memoriał ppłk. dypl. Mariana Drobika Bieżąca polityka polska a rzeczywistość, AAN, Armia Krajowa, cz. II, I/45, s. 2-17. Dokument ten opublikował Józef Stępień. J. Stępień, Memoriat ppłk. dypl. Mariana Drobika z listopada 1943 r. w sprawie zmiany polityki Polski wobec ZSRR, „Teki Archiwalne” 2006, Nowa Seria, t. VI (XXVIII), s. 172-176 (wstęp), 177 (dok. nr 1, Pismo przewodnie ppłk. dypl. Mariana Drobika do memorandum pt. „Ściśle tajne. Bieżąca polityka polska a rzeczywistość”, 8 XI 1943 r.), s. 177-197 (dok. nr 2, Memoriał ppłk. dypl. Mariana Drobika „Ściśle tajne. Bieżąca polityka polska a rzeczywistość", 7 XI 1943 r.); W. Bułhak, op. cit., s, 28-41.

${ }^{76}$ Mikołajczyk pod presją Churchilla był wówczas gotów pójść na daleko idące ustępstwa w sprawie polskiej granicy wschodniej. Jednak spotkał się nie tylko z oporem członków rządu RP na wychodź- 
za najczarniejszy w dziejach Delegatury. Natomiast Narodowe Siły Zbrojne, poznawszy teść memoriału, wydały na jego autora wyrok śmierci, o czym Sekcję Spraw Zagranicznych zawiadomił dyrektor Departamentu Spraw Wewnętrznych Delegatury Leopold Rutkowski ${ }^{77}$.

Trudno o jednoznaczną ocenę propozycji zawartych w memoriale z kwietnia $1944 \mathrm{r}$. Analitycy, tacy jak Knoll i Drobik, popełniali błąd, sądząc, że ustępstwa terytorialne na rzecz Związku Sowieckiego pozwolą Polsce zachować niepodległość. Moskwa realizowała wówczas przede wszystkim cele imperialne Rosji, a najpewniejszym środkiem ich urzeczywistniania było budowanie wokół granic Związku Sowieckiego bloku państw „zaprzyjaźnionych", w których wcześniej czy później władzę przejmowały partie komunistyczne. Nie należy jednak wykluczyć, że w końcu 1943, czy może jeszcze nawet na początku 1944 r. istniała szansa na powrót do kraju rządu RP, po zaakceptowaniu tzw. linii Curzona jako przyszłej wschodniej granicy państwa polskiego ${ }^{78}$, na warunkach podobnych do tych, na jakich do Pragi powrócili Edvard Beneš i czechosłowacki rząd emigracyjny ${ }^{79}$. Najprawdopodobniej także w przypadku Polski finał byłby jednak analogiczny jak w Czechosłowacji w $1948 \mathrm{r}^{80}$ Knoll miał świadomość, że większość atutów pozostaje w rękach Józefa Stalina, i dopuszczał możliwość odrzucenia przez Moskwę polskich propozycji. Jednak uważał, że gotowość

stwie, ale przede wszystkimi kierownictwa polskiego państwa podziemnego. J. Tebinka, op. cit., s. 316, $317,322,323,331$.

77 A. Leśniewski, Memoriał..., s. 95. Natomiast Witold Kamieniecki twierdzi, że Knoll w 1944 r. musiał ukrywać się przed „niepoczytalną frakcją ONR”, ponieważ znalazł się na sporządzonej przez nią liście proskrypcyjnej rzekomych masonów i Żydów i „groziło mu niebezpieczeństwo skrytobójczego zamachu lub denuncjacji”. W. Kamieniecki, op. cit., s. 151. Dowodem, że zagrożenie życia szefa Sekcji Spraw Zagranicznych Delegatury istniało, było zabójstwo Makowieckiego i Widerszala oraz niewyjaśnione okoliczności aresztowania Drobika. A. Zahorski, op. cit., s. 490; A. Gieysztor, op. cit., s. 225; W. Bułhak, op. cit., s. 47 i n.

${ }^{78}$ Związek Sowiecki, powołując do życia na początku 1943 r. Związek Patriotów Polskich, planował wyłączenie legalnych władz Rzeczypospolitej z gry o powojenną Polskę. Natomiast Stalin w grudniu 1943 r., rozmawiając z przebywającym w Moskwie prezydentem Czechosłowacji Edvardem Benešem, sugerował, że możliwe byłoby wznowienie stosunków polsko-sowieckich, jednak po spełnieniu trzech warunków: przyjęcia przez stronę polską ustaleń konferencji teherańskiej w sprawie granic, rekonstrukcji rządu i rezygnacji z polityki antysowieckiej. Dyktator sowiecki najwyraźniej nie szukał wówczas porozumienia z legalnymi władzami RP, a raczej zamierzał przyciągnąć niektórych polskich polityków emigracyjnych do kolaboracji z Moskwą. Rzeczywiste plany Sowietów wobec Rzeczypospolitej zawiera także notatka członka komisji Biura Politycznego KC WKP(b), powołanej 4 IX 1943 r., Iwana Majskiego O pożądanych zasadach przyszłego pokoju sporządzona 11 I 1944 r., w której znalazło się stwierdzenie, że Związek Sowiecki nie powinien być zainteresowany odrodzeniem dużego terytorialnie oraz silnego politycznie i gospodarczo państwa polskiego, w przeciwieństwie do Czechosłowacji. H. Bartoszewicz, Polityka Związu Sowieckiego wobec państw Europy Środkowo-Wschodniej w latach 1944-1948, Warszawa 1999, s. 22, 28, 29, 31, 32.

${ }^{79}$ Beneš sądził, że podpisując 12 XII 1943 r. czechosłowacko-sowiecki Układ o przyjaźni, wzajemnej pomocy $i$ wspótpracy powojennej zagwarantuje Czechosłowacji niezawisłość i suwerenność. W rzeczywistości polityka prezydenta Czechosłowacji wobec dążącego do ekspansji terytorialnej i ustrojowej Związku Sowieckiego skazana była na niepowodzenie. W marcu 1945 r. Stalin, zmuszając Beneša do włączenia w skład rządu czechosłowackiego komunistów i do oddania Związkowi Sowieckiemu Rusi Podkarpackiej, faktycznie objął kuratelę nad okrojoną Czechosłowacją. M. K. Kamiński, Edvard Beně̌ we wspótpracy z Kremlem. Polityka zagraniczna władz czechosłowackich na emigracji 1943-1945, Warszawa 2009, s. 98, 99, 255-259.

${ }^{80}$ W Czechosłowacji ostatecznie komuniści przejęli pełnię władzy w lutym 1948 r. Idem, W obliczu sowieckiego ekspansjonizmu. Polityka Stanów Zjednoczonych i Wielkiej Brytanii wobec Polski i Czechostowacji 1945-1948, Warszawa 2005, s. 306. 
rządu RP do ustępstw w kwestii granicy wschodniej i ujawnienie władz polskich przejmujących administrację na terenach wyzwalanych spod okupacji niemieckiej „może związać ręce zaborczości sowieckiej, zmuszając Rosję do wyboru między porozumieniem z legalną władzą [polską], wspartą uznaniem Anglosasów, a otwartym podbojem Polski, który by poważnie zagrażał pozycji Rosji w świecie alianckim i neutralnym"s1. Knoll najwyraźniej nie doceniał ówczesnej pozycji międzynarodowej Związku Sowieckiego i przeceniał determinację Wielkiej Brytanii, a zwłaszcza Stanów Zjednoczonych, w zmaganiach o zapewnienie Polsce niezawiłości i suwerenności.

Oceny polskiej polityki zagranicznej dwudziestolecia międzywojennego i doby drugiej wojny światowej, a także propozycje niektórych jej kierunków w okresie przejścia od wojny do pokoju, zawarte w opracowaniach i memoriałach Romana Knolla, które powstały między marcem 1939 a kwietniem 1944 r., pomimo wielu dyskusyjnych tez, a może właśnie dlatego, zasługują na uwagę. Nie należy wykluczyć, jak twierdzi Witold Kamieniecki, że surowe sądy Knolla o polskiej polityce zagranicznej po 1932 r. wynikały z jego niechęci do Becka ${ }^{82}$. Jednak niektóre $\mathrm{z}$ tych ocen nie były bezzasadne i należy dodać, że odnosiły się przede wszystkim do okresu po śmierci Józefa Piłsudskiego. Trudno nie zgodzić się z twierdzeniem Knolla o asymetrii stosunków na linii Warszawa-Berlin i Warszawa-Moskwa, z wyraźną przewagą na korzyść tych pierwszych, chociaż nie czynił on zarzutu ówczesnemu szefowi dyplomacji polskiej z powodu odchodzenia przez niego od polityki „równowagi”. Oskarżał jedynie Becka, że nie potrafił dostrzec w porę grożącego Polsce niebezpieczeństwa ze strony Niemiec. Wydaje się, że wiosną 1939 r. Knoll widział więcej niż inni — możliwość sojuszu niemiecko-sowieckiego, który był wówczas największym zagrożeniem dla Polski.

W polskiej polityce wschodniej Knoll za sprawę niezmiennie istotną uważał wspieranie wyzwalania narodów zdominowanych przez Rosję i budowę wokół jej granic niepodległych państw narodowych. Opowiadał się za utworzeniem niepodległego państwa ukraińskiego, ale w okresie trwającej wojny był przeciwny podejmowaniu dyskusji o ,wielkiej Ukrainie”. Podkreślał, że Polska, rozważając problem litewski, białoruski czy ukraiński, powinna przede wszystkim dbać o integralność własnego terytorium. Nawet w kwietniu 1944 r., kiedy dopuszczał możliwość dokonania przez Polskę ustępstw w sprawie granicy wschodniej, traktował to rozwiązanie jako zło konieczne i miał świadomość, że Związek Sowiecki stanowi bardzo poważne zagrożenie dla niepodległości i niezawisłości Rzeczypospolitej.

Opinie Knolla w sprawie sytuacji ludności żydowskiej w Polsce pod okupacją niemiecką i sowiecką nie różniły się zasadniczo od ocen zawartych w innych dokumentach sporządzonych w czasie wojny przez przedstawicieli polskiego państwa podziemnego i władz RP na wychodźstwie. Szef Sekcji Spraw Zagranicznych, jak i inni przedstawiciele Delegatury, rzetelnie informował o eksterminacji ludności żydowskiej na ziemiach polskich włączonych w granice Trzeciej Rzeszy oraz na terytorium Generalnego Gubernatorstwa. Jednocześnie istniała między autorami memorandów zgodność w kwestii położenia Żydów pod okupacją sowiecką. Knoll pisał dosyć oględnie o ,gwałtowności ruchu żydowskiego na terenach zajętych przez Rosję sowiecką". W memoriałach innych reprezentantów ówczesnych władz

\footnotetext{
${ }^{81}$ Dwa memoriały..., dok. nr 2, s. 244. Także Drobik miał wątpliwości dotyczące celowości dążenia do porozumienia ze Związkiem Sowieckim za cenę daleko idących ustępstw. Pisał między innymi: „Jednym z najpopularniejszych argumentów przeciw temu porozumieniu jest twierdzenie, że i tak ono do niczego nie doprowadzi, gdyż Rosja zobowiązań nie dotrzymuje, a my przez ustępstwa dostarczymy jej tylko usprawiedliwienia dla jej imperialnej polityki wobec reszty świata”. J. Stępień, op. cit., dok. nr 2, s. 193.

${ }^{82}$ W. Kamieniecki, op. cit., s. 151.
} 
polskich mowa jest o współpracy Żydów z milicją sowiecką i NKWD oraz lepszym ich traktowaniu przez okupanta sowieckiego niż Polaków i Ukraińców. Niezbyt szczęśliwe były pomysły Knolla dotyczące przesiedlenia Żydów do specjalnie utworzonego dla nich państwa, ale polski dyplomata nie był wówczas jedynym politykiem, który o tym mówił i pisał. Takie rozwiązanie powojennych losów ludności żydowskiej przesiedlonej z terytorium Europy Środkowo-Wschodniej rozważano w Londynie i Waszyngtonie. Nie było ono obce także niektórym spośród przedstawicieli zachodnich środowisk żydowskich.

Słowa kluczowe: polityka zagraniczna, sprawy narodowościowe, prometeizm, polskie państwo podziemne, memorandum

\section{Bibliografia}

Bartoszewicz H., Misja dyplomatyczna Romana Knolla w Rzymie, „Dzieje Najnowsze” 2011, r. XLIII, nr 1, s. 53-76.

Bartoszewicz H., Misja Romana Knolla w Ankarze 1924-1925, „Studia z Dziejów Rosji i Europy Środkowo-Wschodniej" 2001, t. XXXVI, s. 109-125.

Bartoszewicz H., Okres rosyjski w karierze dyplomatycznej Romana Knolla, cz. 1, „Studia z Dziejów Rosji i Europy Środkowo-Wschodniej” 2004, t. XXXIX, s. 63-82; cz. 2, „Studia z Dziejów Rosji i Europy Środkowo-Wschodniej” 2005, t. XL, s. 63-80.

Bartoszewicz H., Polityka wschodnia II Rzeczypospolitej $w$ świetle polskich dokumentów dyplomatycznych 1931 r., „Dzieje Najnowsze” 2009, r. XXXI, nr 4, s. 17-143.

Bartoszewicz H., Polityka Zwiazku Sowieckiego wobec państw Europy Środkowo-Wschodniej w latach 1944-1948, Warszawa 1999.

Bartoszewicz H., Roman Knoll wobec sprawy niepodległości Ukrainy 1917-1921. Z dziejów prometeizmu polskiego, „Polska i jej wschodni sąsiedzi” 2005, t. VI, s. 11-30.

Bartoszewski W., 1859 dni Warszawy, wyd. II, Kraków 1984.

Bruski J. J., Londyn-Bukaresz-Stambut. Przyczynek do działalności Włodzimierza Bączkowskiego w latach 1939-1940, „Nowy Prometeusz” 2015, nr 5, s. 179-210.

Bruski J. J., W kregu spraw prometejskich i ukrainskich. Jerzy Giedroyc w Rumunii 1939-1941, w: Giedroyc i Ukraina. Ukraińska perspektywa Jerzego Giedroycia i środowiska paryskiej „Kultury”, red. M. Szymczyszyn, M. Zajączkowski, Warszawa-Lublin-Szczecin 2014, s. $72-90$.

Bułhak W., Raport szefa Oddziatu II KG AK pptk. dypl. Mariana Drobika „Bieżaca polityka polska a rzeczywistość" i sprawa jego aresztowania (listopad-grudzień 1943), w: Wywiad i kontrwywiad Armii Krajowej, red. W. Bułhak, Warszawa 2008, s. 15-77.

Dwa memoriały Romana Knolla (z września 1943 r. oraz z kwietnia 1944 r.) $w$ sprawie kształtu bieżacej polskiej polityki zagranicznej $i$ jej założeń na okres powojenny, wyd. A. G. Dąbrowski, „Teki Archiwalne” 2011, t. XI(XXXIII), s. 209-245.

Gieysztor A., Makowiecki Jerzy, pseud. Mirewicz, Tomasz, Malicki, Wokulski, Kuncewicz (18901944), Polski słownik biograficzny, t. XIX, Wrocław-Warszawa-Kraków-Gdańsk 1974, s. $224,225$.

Jankowski S. M., Karski. Raporty tajnego emisariusza, Poznań 2010.

Kaczkowska A., Pamięci Romana Knolla, „Kultura”, nr 1-2 (135-136), Paryż 1959, s. 195-204.

Kamieniecki W., Historycy i politycy warszawscy 1900-1950, Wrocław 1992.

Kamiński M. K., Edvard Beneš we współpracy z Kremlem. Polityka zagraniczna władz czechosłowackich na emigracji 1943-1945, Warszawa 2009.

Kamiński M. K., W obliczu sowieckiego ekspansjonizmu. Polityka Stanów Zjednoczonych i Wielkiej Brytanii wobec Polski i Czechosłowacji 1945-1948, Warszawa 2005.

Knoll R., Uwagi o polskiej polityce 1939, Warszawa 1939.

Kornat M., Polska 1939 roku wobec paktu Ribbentrop-Mołotow, Warszawa 2002. 
Leśniewski A., Departament Spraw Zagranicznych — kryptonim „,Moc”, 630/Z-Delegatury Rzadu RP na Kraj, w: Władze RP na obczyźnie podczas II wojny światowej, red. Z. Błażyński, Londyn 1994, s. 624-635.

Leśniewski A., Memoriat ministra Romana Knolla z 1944 roku, w: Materiaty do dziejów polskiego uchodźstwa niepodległościowego 1939-1990, uzupełnienia do tomów I, II, V, VI, red. Z. Błażyński, Londyn 1996, s. 92-100.

Libionka D., ZWZ-AK i delegatura rządu wobec eksterminacji Żydów polskich, w: Polacy $i \dot{Z} y d z i$ pod okupacja niemiecka 1939-1945. Studia i materiały, red. A. Żbikowski, Warszawa 2006, s. 15-175.

Memoriat ppłk. dypl. Mariana Drobika z listopada 1943 r. w sprawie zmiany polityki Polski wobec ZSRR, oprac. J. Stępień, „Teki Archiwalne”, Nowa Seria 2001, t. VI (XXVIII), s. 172-197.

Michowicz W., Organizacja polskiego aparatu dyplomatycznego w latach 1918-1939, w: Historia dyplomacji polskiej, t. IV: 1918-1939, red. P. Łossowski, Warszawa 1995, s. 5-78.

Michowicz W., Organizacja stużby dyplomatycznej w okresie II wojny światowej, w: Historia dyplomacji polskiej, t. V: 1939-1945, red. W. Michowicz, Warszawa 1999, s. 9-105.

Müller R. D., Wspólny wróg. Hitlerowskie Niemcy i Polska przeciw Związkowi Radzieckiemu, Warszawa 2013.

Polskie Dokumenty Dyplomatyczne 1940, red. M. Hułas, Warszawa 2010.

Protokoły Posiedzeń Rady Ministrów Rzeczypospolitej Polskiej, t. V: wrzesień 1942-lipiec 1943, red. M. Zgórniak, oprac. W. Rojek, przy współpr. S. Suchcitza, Kraków 2001.

Stępniak W., Dyplomacja polska na Bałkanach (1918-1926), Warszawa 1998.

Stola D., Nadzieja i zagłada. Ignacy Schwarzbart - zydowski przedstawiciel w Radzie Narodowej $R P$ (1940-1945), Warszawa 1995.

Tebinka J., Polityka brytyjska wobec problemu granicy polsko-radzieckiej 1939-1945, Warszawa 1998.

Torzecki R., Polacy i Ukraińcy. Sprawa ukrainska w czasie II wojny światowej na terenie II Rzeczypospolitej, Warszawa 1993.

Wandycz P., Z Pitsudskim i Sikorskim. August Zaleski minister spraw zagranicznych $w$ latach 1926-1932 i 1939-1941, Warszawa 1999.

Wandycz P., Z zagadnień wspótpracy polsko-ukraińskiej w latach 1919-1920, „Zeszyty Historyczne", z. 12, Paryż 1967, s. 3-24.

Zahorski A., Ludwik Widerszal (1909-1944), w: Historycy warszawscy ostatnich dwóch stuleci, Warszawa 1986, s. 489, 490.

\section{Roman Knoll and His Assessments of the Past and Visions of the Future}

The article focuses on studies and memorials by Roman Knoll concerning international affairs, Polish foreign policy, and national problems, written between March 1939 and April 1944. Assessments of Polish inter-war and wartime foreign policy, contained in those documents, and proposals regarding some of its post-war currents deserve special attention. Numerous theses proposed by Knoll should be regarded as extremely apt. It would be difficult, for instance, to disagree with his opinion about asymmetrical Warsaw-Berlin and Warsaw-Moscow relations, revealing a distinct advantage in favour of the former. Apparently, in the spring of 1939 Knoll, in contrast to other observers, perceived the possibility of a German-Soviet alliance, which at the time posed the greatest threat to Poland.

Within Polish eastern policies this outstanding diplomat regarded as essential support for the liberation of nations dominated by Russia and the construction around the latter's borders of independent national states. He espoused the creation of an independent Ukrainian state, but at the time of the war opposed embarking upon a discussion about "great Ukraine". In doing so, Knoll stressed that while considering the Lithuanian, Byelorussian or Ukrainians questions Poland should remain concerned predominantly with the integrity of its territory. Even in April 1944, when he admitted to the possibility of Poland accepting concessions concerning the eastern 
frontier, he treated such a solution as a necessary evil and was well aware of the fact that the Soviet Union remained a hazard to the independence and sovereignty of the Polish Republic.

Knoll presented reliable accounts of the wartime situation of the Jewish population on Polish lands and depicted the extermination of the Jews in terrains included into the Third Reich and the territory of the Generalgouvernement. At the same time, he wrote about the Soviet occupant's better treatment of the Jews than of the Poles and the Ukrainians. In the prevailing situation it was difficult to accept his projects concerning a post-war resettlement of the Jews to a state specially created for them, but the Polish diplomat was by no means the sole politician who at the time wrote and spoke about this issue. 